\title{
High fire frequency reduces soil fertility underneath woody plant canopies of Mediterranean ecosystems
}

\author{
M. Belén Hinojosa ${ }^{\mathrm{a}, *}$, Enrique Albert-Belda ${ }^{\mathrm{a}}$, Beatriz Gómez-Muñoz ${ }^{\mathrm{b}}$, José M. Moreno ${ }^{\mathrm{a}}$ \\ a Departamento de Ciencias Ambientales, Universidad de Castilla-La Mancha, Campus Fábrica de Armas, E-45071 Toledo, Spain \\ b Department of Plant and Environmental Sciences, Faculty of Science, University of Copenhagen, Thorvaldsensvej 40, Frederiksberg 1871, Denmark
}

\section{H I G H L I G H T S}

- Knowledge about interaction between plants and soil under recurrent fires is limited.

- Fire frequency effect on soil fertility is tested in different microsites.

- Soil microsite fertility is speciesdependent and is affected by fire frequency.

- High fire frequency decreases the positive effect of woody plants on soil fertility.

- Decreased N:P ratio with increasing fire frequency is species dependent.

\section{A R T I C L E I N F O}

\section{Article history:}

Received 27 February 2020

Received in revised form 19 August 2020

Accepted 20 August 2020

Available online 24 August 2020

Editor: Paulo Pereira

\section{Keywords:}

Fire recurrence

Soil spatial heterogeneity

Soil fertility

Leaf nutrient content

Litter nutrient content
G R A P H I C A L A B S T R A C T

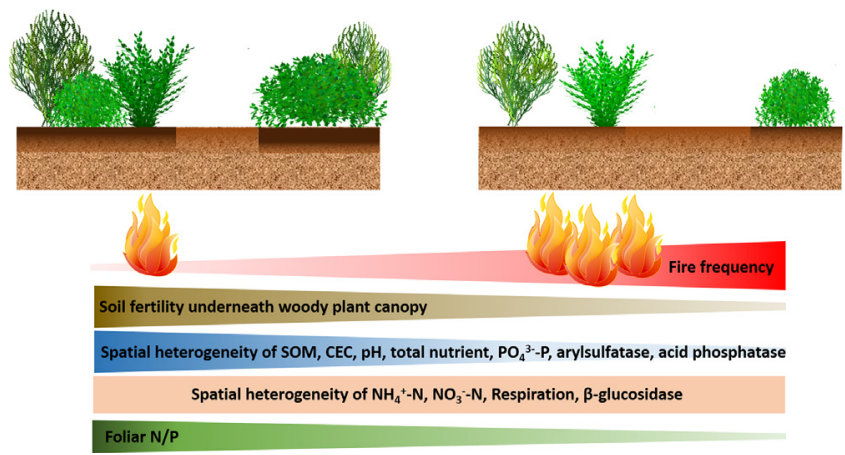

\section{A B S T R A C T}

Spatial heterogeneity of soil properties plays a major role in regulating ecosystem structure and functioning. In general, soil resources accumulate beneath woody plant-covered patches more than in the open interspace, making them function as fertility islands. Whilst wildfire is a common disturbance, little information is available on the role of particular plant species in maintaining soil fertility underneath in areas that are subjected to recurrent fires. This is an important issue given that land abandonment, together with a warmer and drier climate, is increasing fire danger in regions such as the Mediterranean. We determined whether increasing fire frequency, producing changes from a Quercus ilex L., woodland to a shrubland, modifies the effect of woody plant canopy on soil fertility. Additionally, the effect of fire history on species-specific leaf and litter nutrient concentration was assessed. Areas affected by none, one, two or three fires were selected. Within each area, soil fertility was measured underneath Cistus ladanifer L., Retama sphaerocarpa L., Phillyrea angustifolia L. and Quercus ilex canopies and in open interspace. Unburned soils located underneath P. angustifolia and Q. ilex canopies were significantly more fertile than in open interspaces. The microsite effect on soil fertility was fire frequency dependent. As fire frequency increased, the plant canopy microsite effect decreased for soil organic matter (SOM), cation exchange capacity (CEC), total C, P, Ca, K and Mg, labile phosphate, arylsulfatase and acid phosphatase activities. Total N, ammonium, nitrate and $\beta$-glucosidase activity decreased with increasing fire frequency, but their spatial variability was maintained along all fire frequency scenarios. Fire frequency decreased foliar $\mathrm{N}$ concentration but increased $\mathrm{P}$ concentration in some species, leading to a decrease in their N:P ratio. Our findings suggest that soil fertility heterogeneity will be reduced with increasing fire frequency. This could compromise the recovery of soil and ecosystem functioning.

c) 2020 Elsevier B.V. All rights reserved.

\footnotetext{
* Corresponding author.

E-mail address: mariabelen.hinojosa@uclm.es (M.B. Hinojosa).
} 


\section{Introduction}

Spatial heterogeneity of soil properties plays a major role in ecosystem structure and functioning (Ettema and Wardle, 2002; García-Palacios et al., 2012). This is particularly evident in ecosystems with discontinuous vegetation that are characterized by "fertility islands", i.e., soil patches due to the accumulation of soil particles beneath plant canopies, and bare patches (Bond, 2019). This results in a contrasting distribution of soil resources and functioning between the bare areas (open interspaces) and those beneath the canopies. Open interspaces are more exposed to soil erosion and beneath canopy areas tend to accumulate soil (Schlesinger et al., 1990). Beneath plant canopies, soil surfaces erode at slower rates than in the open interspaces, thus creating a positive feedback that accentuates the development of plant mounds beneath the canopies and interspaces with lower elevations (D'Odorico et al., 2012; Wang et al., 2019). The initiation and persistence of fertility islands is due to both abiotic and biotic processes, as for example, trapping of windblown material, directional transport of soil by differential rain splash or litter deposition beneath plants ( $\mathrm{Li}$ et al., 2017). The type and number of plant species regulate the quality and quantity of litter, root exudates and detritus, nutrient requirements, soil water availability and temperature, all of which can influence soil nutrient cycling (Dahlgren et al., 1997; Titus et al., 2002; Sardans and Peñuelas, 2013).

Wildfires are recurrent ecological disturbances in forest, shrubland and grassland ecosystems worldwide (Krawchuk et al., 2009). Wildfires are common in Mediterranean-type areas due to their highly flammable vegetation and long, warm and dry summers (Keeley et al., 2011; Rundel et al., 2018).

Fire can increase soil nutrient availability by SOM pyromineralization, as fire converts biomass into ash (Neary et al., 1999; Caon et al., 2014). There are multiple factors modulating spatial heterogeneity of post-fire soil fertility. In the short term, fires temporarily remove a large fraction of the aboveground vegetation, litter and a large part of the organic layer, enhancing erosion until vegetative cover is re-established (Neary et al., 1999). Soil water repellence could be induced below the surface in the vegetated microsites when sufficiently high temperatures and high severity are reached. This fact could accelerate runoff at a patch scale and soil erosion (Sankey et al., 2012). At microsites underneath woody plant canopy, greater amounts of litter and biomass may induce higher fire severity, thus further heats the underlying soil (Santana et al., 2011). Conversely, open spaces without vegetation may burn with lower severity. Wind and slope can also affect heat distribution (Odion and Davis, 2000). According to Weise and Biging (1996), the effect of wind is to tilt the flame relative to the fuel and to affect radiant and convective heat transfer. The inclusion of slope potentially changes the view factor between the flame and the fuel and further changes radiant heat transfer.

Fire-prone ecosystems are characterized by different regeneration functional groups (resprouters and seeders (Keeley et al., 2011)). It has been argued that differences between resprouters and seeders determine the formation of fertility islands in burned ecosystems (Mayor et al., 2016a). López-Poma and Bautista (2014) assessed how these plant functional regeneration types modulate soil microbial and biochemical response to fire, demonstrating the important role of resprouter species in the plant-soil system. Most resprouter individuals can survive after fire, recovering their above-ground biomass relatively quickly at the same location, thus leading to continued accumulation of soil organic matter (SOM) underneath them. However, seeders may have lower accumulation of SOM underneath them due to the fact that they are killed by fire, and the new individuals may become established from seeds in different locations than the pre-fire ones. In addition, different plants vary in several ways including in their leaf nutrient content, biomass distribution to either below or aboveground growth, and litter decomposition rates (Verdú, 2000; Saura-Mas and Lloret, 2009).
Previous studies have evaluated soil spatial heterogeneity after fire depending on the type of vegetation that was burned. Sankey et al. (2012) demonstrated that the spatial patterning of soil nutrients in sagebrush steppe, in which soils beneath shrubs are enriched, is resilient to burning (i.e. it rapidly recovers after fire). They reported that relatively long fire intervals (from decades to centuries) intensify the spatial patterning of soil properties. They also suggested that elevated fire frequency might affect soil properties at the microsite level.

Research assessing the effect of wildfire history on nutrient cycling and soil fertility showed that, when fire frequency is particularly high, this may result in additive nutrient losses through losses by smoke particles, windblown ash, volatilization, soil erosion and leaching. These processes disrupt the long-term balance between nutrient inputs related to succession and nutrient outputs due to fire (Carreira et al., 1994; Ferran et al., 2005; Guénon et al., 2013; Pellegrini et al., 2018). Mayor et al. (2016b) reported losses in soil fertility with increasing fire recurrence in areas where fire promotes a shift from pine woodlands to shrublands. Soil fertility losses were particularly high at the microsites between shrubs. However, more research is required in order to understand the role of individual woody plant canopies, in interaction with fire frequency, to modulate soil fertility in other fireprone ecosystems.

Quercus ilex L. woodlands are widespread in the Mediterranean region and they have been subjected to intensive uses like grazing, charcoal production and even agriculture (de Rigo and Caudullo, 2016). Their abandonment is leading to encroachment by shrubs (Baudena et al., 2020) and to more frequent burning (Urbieta et al., 2019). Little is known about the resilience of the soil-plant system to recurrent fires in this type of ecosystem (de Román and de Miguel, 2005). To our knowledge no previous studies have evaluated the role of seeders and resprouters in soil fertility at the microsite scale after recurrent fires in Q. ilex L. woodlands.

The purpose of our study was to fill some of these knowledge gaps. Our aim was to evaluate how fire history modifies biogeochemical soil properties underneath woody plant canopies (resprouters and seeders) in a $Q$. ilex woodland that, as a result of increasing fire frequency, turned into a shrubland. Additionally, we investigated whether plants demonstrate species-specific responses in their nutrient concentration as a consequence of increased fire frequency.

\section{Material and methods}

\subsection{Study sites}

The study was carried out in Argamasilla de Calatrava (province of Ciudad Real, Spain) $\left(38^{\circ} 42^{\prime} \mathrm{N}-4^{\circ} 01^{\prime} \mathrm{W}\right)$. The altitude of the study area ranges from 700 to $800 \mathrm{~m}$ a.s.l. and the slope from $22^{\circ}$ to $38^{\circ}$, being the dominant aspects southeast and northeast. The climate is classified as Mediterranean, Csa (Beck et al., 2018); average annual rainfall is $489 \mathrm{~mm}$ and average annual temperature is $14.3^{\circ} \mathrm{C}$ (1980-2015 period) (Climatic Research Unit TS V4.01; Harris et al., 2014). Soil type is sandy loam Inceptisols (Soil Survey Staff, 2006), derived from slates and quartzites.

The study site is a former $Q$. ilex woodland. Different areas within the site have different fire histories. Due to increasing fire frequency, the woodland is becoming dominated by shrubs. We focused on four wildfires that occurred in 1986, 2001, 2005 and 2008. These wildfires were chosen to delimit areas that were burned once, twice or three times in the 32 years that elapsed between the first and the last fire (Table S.1; Supplementary material). In the case of areas burned twice, both short (2-S) and long (2-L) interval between fires were considered. The time that had elapsed since the last fire was not the same for all plots ( 7 and 10 years); however, we assumed that this difference between the plots was not important, and therefore it was appropriate to use a diachronic approach to test the effect of fire frequency in the medium term. 
For each fire history, we selected three $30 \times 30 \mathrm{~m}$ plots for sampling. In addition, three plots in nearby areas, unburned for at least the last 68 years, were selected as controls (long-term unburned plots, zero fires). The fire history and location of the 15 study plots are described in Table S.1. In burned study plots, fire severity was moderate to low. The delta normalized burn ratio (dNBR), widely used as fire severity index, was computed with the Google Earth Engine (GEE) platform based on Landsat images. In the study plots the dNBR values were $0.20-0.39,0.14-0.16,0.25-0.39$ and $0.20-0.31$; for wildfires that occurred in 1986, 2001, 2005 and 2008, respectively.

The unburned plots were mainly covered by mature $Q$. ilex trees (resprouter). The burned plots were dominated by shrubs, mainly Cistus ladanifer L. (seeder), Retama sphaerocarpa L. (resprouter, Leguminosae) and Phillyrea angustifolia L. (resprouter). There were individuals of all four species in every study plot. Table S.2 describes in detail the composition and structural characteristics of the vegetation present in the plots representative of the fire scenarios studied.

\subsection{Foliar, litter and soil sampling}

Leaves, litter and soil samples were collected at the end of the growing season (June to July 2015). Five individuals of each of the four species previously mentioned were randomly selected at each plot (i.e. $C$. ladanifer, $R$. sphaerocarpa, $P$. angustifolia, and $Q$. ilex). Samples of leaves from apical branches $10 \mathrm{~cm}$ long, litter $(30 \times 30 \mathrm{~cm}$ square $)$ and soil ( $7 \mathrm{~cm}$ diameter and $5 \mathrm{~cm}$ depth cores) were taken in the four cardinal directions of each plant, to form a single composite sample per individual. Additionally, in open areas without woody cover, five composite soil samples per plot were taken. Thus, in order to collect these soil samples from open interspaces, four soil sub-samples were taken in each of the four quarters of five circles, which centres were randomly selected within each plot, and the samples were mixed into a composite one per open interspace. In total, 300 leaf samples, 300 litter samples and 375 soil samples were collected in this study.

Soil samples were transported in an isothermal bag $\left(4^{\circ} \mathrm{C}\right)$ to the laboratory, where they were immediately sieved $(<2 \mathrm{~mm})$ and air dried. Samples were analysed within six weeks after sampling. Leaves and litter samples were dried at $70{ }^{\circ} \mathrm{C}$ for $48 \mathrm{~h}$ and ground with a ball mill (Retsch 20.741.0004) ready for analysis.

\subsection{Soil analysis}

Soil $\mathrm{pH}$ was determined in a slurry with $\mathrm{CaCl}_{2}$ ( $\left.\operatorname{soil}: \mathrm{CaCl}_{2} 1: 1\right)$ following McLean (1982). SOM was measured by weight lost on ignition $\left(550^{\circ} \mathrm{C}\right.$ for $2 \mathrm{~h}$ ) (Nelson and Sommers, 1996). Cation exchange capacity (CEC) was analysed by saturation with NaOAc (Rhoades, 1982). Total carbon $(\mathrm{C})$ and nitrogen $(\mathrm{N})$ content were determined in ground samples using a LECO TruSpec CN analyzer (LECO Corp, MI, USA). Total phosphorus, potassium, calcium and magnesium ( $\mathrm{P}, \mathrm{K}, \mathrm{Ca}, \mathrm{Mg}$ ) were determined in ground soil aliquots, after digestion with $\mathrm{HNO}_{3}$ and $\mathrm{H}_{2} \mathrm{O}_{2}$, using an Ultraclave microwave (Milestone SRL, Milan, Italy), by ICP analysis (ICAP 6500 ICP Spectrometer, Thermo Fischer Scientific, MA, USA). Soil ammonium $\left(\mathrm{NH}_{4}^{+}-\mathrm{N}\right)$ and nitrate $\left(\mathrm{NO}_{3}^{-}-\mathrm{N}\right)$ were analysed by spectrophotometry (Selecta UV-2005), after $2 \mathrm{M} \mathrm{KCl}$ extraction (Keeney and Nelson, 1982). Labile phosphate $\left(\mathrm{PO}_{4}^{3-}-\mathrm{P}\right)$ was extracted in $0.5 \mathrm{M} \mathrm{NaHCO}_{3}$ (pH 8.5) extracts (Olsen and Sommers, 1982) and quantified by the colorimetric method of John (1970). Soil C mineralization rate (or soil basal respiration rate) was determined by the alkalitrap method (Anderson, 1982) on soil samples incubated at 65\% water holding capacity (WHC) for 15 days at $24{ }^{\circ} \mathrm{C}$ in the dark and under aerobic conditions. Acid phosphatase (EC 3.1.3.2, orthophosphoricmonoester phosphohydrolase, acid optimum), arylsulfatase (EC 3.1.6.1, arylsulfate sulfohydrolase) and $\beta$-glucosidase (EC 3.2.1.21, $\beta$-d-glucoside glucohydrolase) activities were determined as described by Tabatabai (1994). An aliquot of soil ( $1 \mathrm{~g}$ ) was incubated with the corresponding substrate at $37^{\circ} \mathrm{C}$ for $1 \mathrm{~h}$. After stopping the reaction with
$\mathrm{CaCl}_{2}$ and a strong alkali ( $\left.\mathrm{NaOH}\right)$, the product (p-nitrophenol, pNP) in the supernatant was measured at $410 \mathrm{~nm}$ using a spectrophotometer (Selecta UV-2005). The criteria for selecting these enzymes was their relative importance in nutrient cycling and the fact that they had previously been shown to be good indicators of fire impact in soil functionality (Hinojosa et al., 2016, 2019).

\subsection{Foliar and litter analysis}

All foliar and litter samples were analysed for percentage $\mathrm{N}$ and $\mathrm{C}$ content, using a LECO TruSpec CN analyzer (LECO Corp, MI, USA). Other nutrients $(\mathrm{P}, \mathrm{K}, \mathrm{Ca}, \mathrm{Mg}$ ) were determined in air-dried ground samples, after digestion with $\mathrm{HNO}_{3}$ and $\mathrm{H}_{2} \mathrm{O}_{2}$, using an Ultraclave microwave (Milestone SRL, Milan, Italy) by ICP analysis (ICAP 6500 ICP Spectrometer, Thermo Fischer Scientific, MA, USA).

\subsection{Data analysis}

The occurrence of wildfires in the Mediterranean region requires a large-scale ecosystem approach. This makes experimental replication challenging (Hurlbert, 1984; Oksanen, 2001). To circumvent this, we treated plots within each fire history as independent, even if doing so constrains the scope of inference that is often associated with field experiments (van Mantgem et al., 2001; Driscoll et al., 2010). Nevertheless, it allowed us to take advantage of the various fires that had occurred in the area. A key advantage of our experimental design is that we were able to compare measurements in burned plots with unburned controls, following well-established procedures for large experimental manipulations without true replication (van Mantgem et al., 2001). A general lineal model (GML) was performed for each soil variable, using "fire history" and "microsite" as main factors and considering "plot" (nested in "fire history") as a random factor. For variables without significant "fire history $\times$ microsite" interaction effect, but with "fire history" effects were followed by a Tukey multiple comparison test to identify significant differences among specific means. Additionally, for each "fire history" level (0, 1, 2-L, 2-S and 3 fires) the significance of microsite effects was tested using one-way ANOVA. One-way ANOVA was also performed for each of the foliar and litter variables measured with "fire history" as a fixed factor. When needed, variables were transformed to meet assumptions of homogeneity of variances (Levene's test) and normal distribution (Shapiro-Wilk test)(i.e. square root transformation for SOM, total C, total N, and arylsulfatase; arcsine of square root transformation for soil basal respiration rate, $\mathrm{NH}_{4}^{+}-\mathrm{N}$ and $\mathrm{NO}_{3}^{-}-\mathrm{N}$ ).

A Principal Component Analysis (PCA), based on the correlation matrix of all standardised soil variables was carried out in order to explore differential responses of soils under the various fire histories and microsites (unrotared). PCA results are displayed in separate graphs to illustrate the differences or similarities among "fire histories", "microsites" and "microsites" within each "fire history". STATISTICA 8.0 (StatSoft, Inc., 2007) was used for all statistical analyses $(\alpha=0.05)$.

\section{Results}

\subsection{Biogeochemical soil properties}

In unburned plots, soils under woody plant canopies showed higher SOM ( $P$. angustifolia and Q. ilex), higher CEC ( $R$. sphaerocarpa, $P$. angustifolia and $Q$. ilex) and higher $\mathrm{pH}(C$. ladanifer, $R$. sphaerocarpa and $P$. angustifolia) than in open interspaces (Fig. 1). The effect of the "fire history $\times$ microsite" interaction factor was significant for SOM $(p<0.001)$, CEC $(p<0.05)$ and $\mathrm{pH}(p<0.05)$. In soils affected by low fire frequency, SOM, CEC and $\mathrm{pH}$ showed higher values under woody plant canopies $(p<0.05)$ than in open interspaces. When fire frequency was the highest (2-S or 3 fires) the effect of plant microsite was reduced for CEC and $\mathrm{pH}(p<0.05)$, or disappeared in the case of SOM (Fig. 1). 

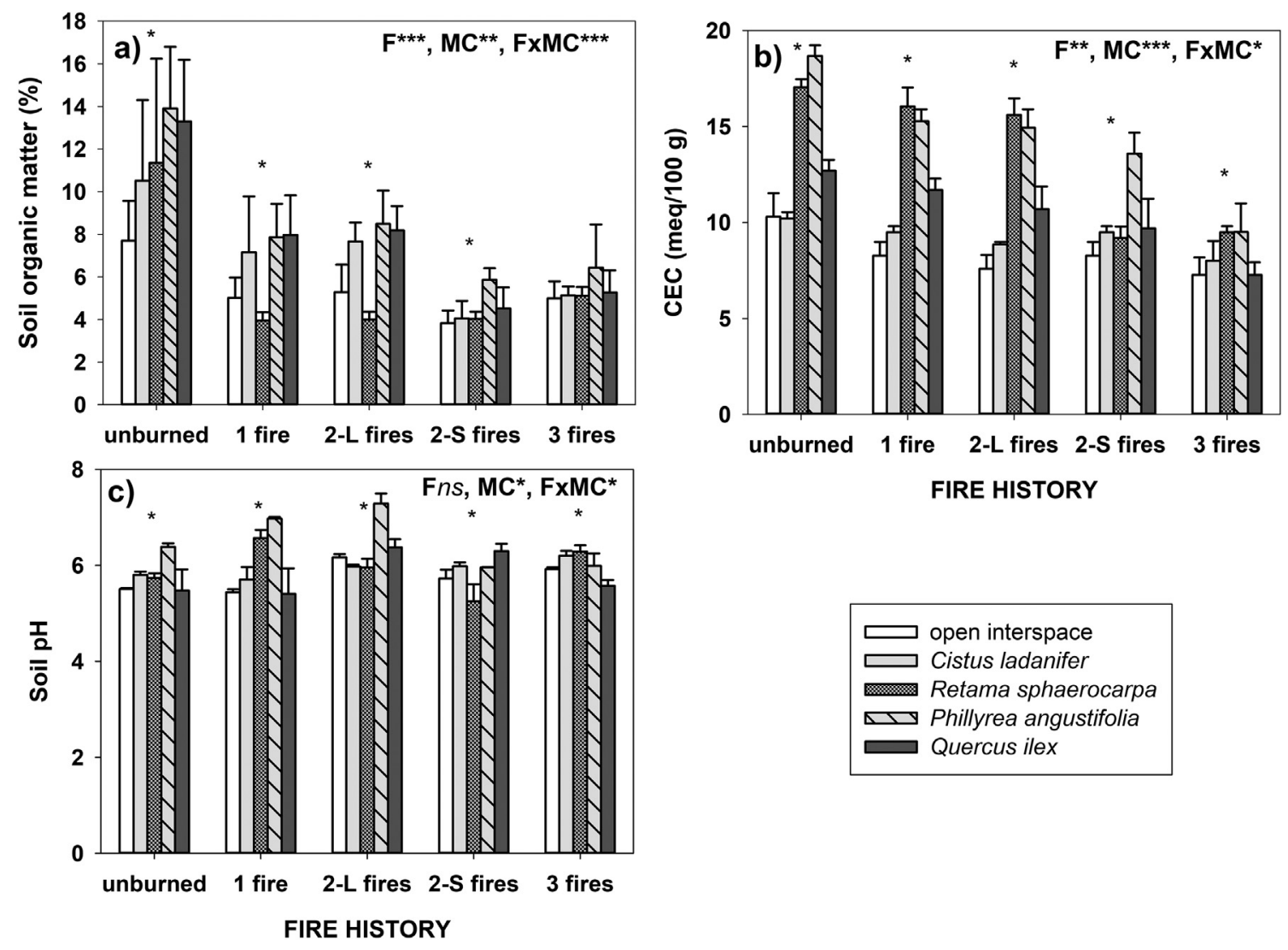

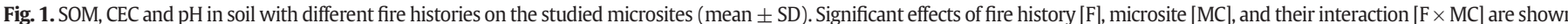
within the figures ( $n s$, no significant effect; ${ }^{*}, p<0.05$; $^{* *}, p<0.01$; $\left.^{* * *}, p<0.001\right)$. Significant effect $(p<0.05)$ of microsite into each fire history scenario is indicated by ${ }^{*}$ over the bars.

Total nutrient concentrations (C, N, P, K, Ca and Mg) of unburned soils were significantly higher under woody plant canopies than in open interspaces, mainly under P. angustifolia and $Q$. ilex $(p<0.05)$ (Fig. 2). The effect of the "fire history $\times$ microsite" interaction factor was significant for all total nutrients $(p<0.05)$. For total nutrient concentrations the significant effect of microsite $(p<0.05)$ observed at low fire frequency tended to disappear as fire frequency increased, except for $\mathrm{Mg}$ whose microsite effect was reduced.

The availability of soil nutrients $\left(\mathrm{NO}_{3}^{-}-\mathrm{N}, \mathrm{NH}_{4}^{+}-\mathrm{N}\right.$ and $\left.\mathrm{PO}_{4}^{3-}-\mathrm{P}\right)$ in unburned soils was significantly higher under plant canopies than in open interspaces, mainly under P. angustifolia or Q. ilex $(p<0.05)$ (Fig. 3). The effect of the "fire history $\times$ microsite" interaction factor was not significant for labile $\mathrm{N}$ inorganic forms. Soil $\mathrm{NO}_{3}^{-}-\mathrm{N}$ and $\mathrm{NH}_{4}^{+}-\mathrm{N}$ concentration significantly decreased with increasing fire frequency $(p<0.05)$. The microsite effect was significant $(p<0.05)$ only for $\mathrm{NH}_{4}^{+}-\mathrm{N}$, with higher values seen under plant canopies, but without a consistent pattern among plant species. For soil $\mathrm{PO}_{4}^{3-}-\mathrm{P}$, there was a significant "fire history $\times$ microsite" interaction effect $(p<0.05)$. As fire frequency increased, the plant canopy microsite effect decreased, until it disappeared in soils affected by three fires.

Soil basal respiration rate and enzyme activity in unburned soils were significantly higher under woody plant canopies than in open interspaces, mainly under R. sphaerocarpa, P. angustifolia and Q. ilex (Fig. 4). Soil basal respiration rate maintained the same value in all fire frequencies, with differences under $P$. angustifolia and $Q$. ilex microsites slightly significant $(p<0.05)$. For arylsulfatase and acid phosphatase activity the effect of microsite tended to disappear as fire frequency increased. $\beta$ Glucosidase activity significantly decreased $(p<0.05)$ with increasing fire frequency and the highest values were observed under plant canopy microsites (mainly P. angustifolia and Q. ilex).

The first two components (PC1 and PC2) resulting from PCA carried out using the whole soil matrix dataset explained $53.5 \%$ of the total variance in the data (Fig. 5, Tables 1, S.3). The first principal component (PC1) can be related to soil fertility and enzyme activity, being SOM, total nutrient concentration ( $\mathrm{C}, \mathrm{N}, \mathrm{P}, \mathrm{Ca}$ and $\mathrm{Mg}$ ), $\mathrm{PO}_{4}^{3-}-\mathrm{P}, \mathrm{NH}_{4}^{+}-\mathrm{N}$ and acid phosphatase and $\beta$-glucosidase activities the variables contributing the most to it, whereas $\mathrm{pH}$ and $\mathrm{CEC}$ were significantly positively correlated (factor loadings of 0.81 and 0.49 , respectively), with second principal component (PC2). $\mathrm{NO}_{3}^{-}-\mathrm{N}$, total $\mathrm{K}$, soil basal respiration rate and arylsulfatase were not significantly related with any of the first two principal components. These two principal components differentiate soil samples according to both fire history and microsite. Thus, when all microsites were pooled together according to their fire history, the biogeochemical properties of soils from unburned plots (with lower $\mathrm{pH}$ and higher soil nutrient availability) were clearly distinguishable from soils affected by two or three fires. Soil burned once occupied an intermediate position (Fig. 5a). In addition, when all fire histories were pooled together for each microsite, the multivariate space discriminated soils of open interspaces (with lower pH and higher soil nutrient availability) from soils under $P$. angustifolia microsites, with the other plant microsites in an intermediate position (Fig. 5b). Fig. 6 explore possible differences among microsites within each fire frequency. In unburned soils, the effect of microsite was a strong discriminating factor. Although C. ladanifer microsites were very similar to open interspaces, the other plant microsites showed clear differences (Fig. 6a). When fire frequency increased, these differences among microsites decreased, with almost no difference among microsites in soils burned three times (Fig. 6b, c, d).

\subsection{Total nutrients in leaf and litter}

The effect of fire frequency was significant for nutrient concentrations ( $, \mathrm{N}, \mathrm{P}, \mathrm{K}, \mathrm{Ca}$ and $\mathrm{Mg})$ of the studied plant species $(p<0.05)$ (Table 2). C. ladanifer, P. angustifolia and Q. ilex decreased their foliar $\mathrm{N}$ concentration with increasing fire frequency. In high fire frequency 

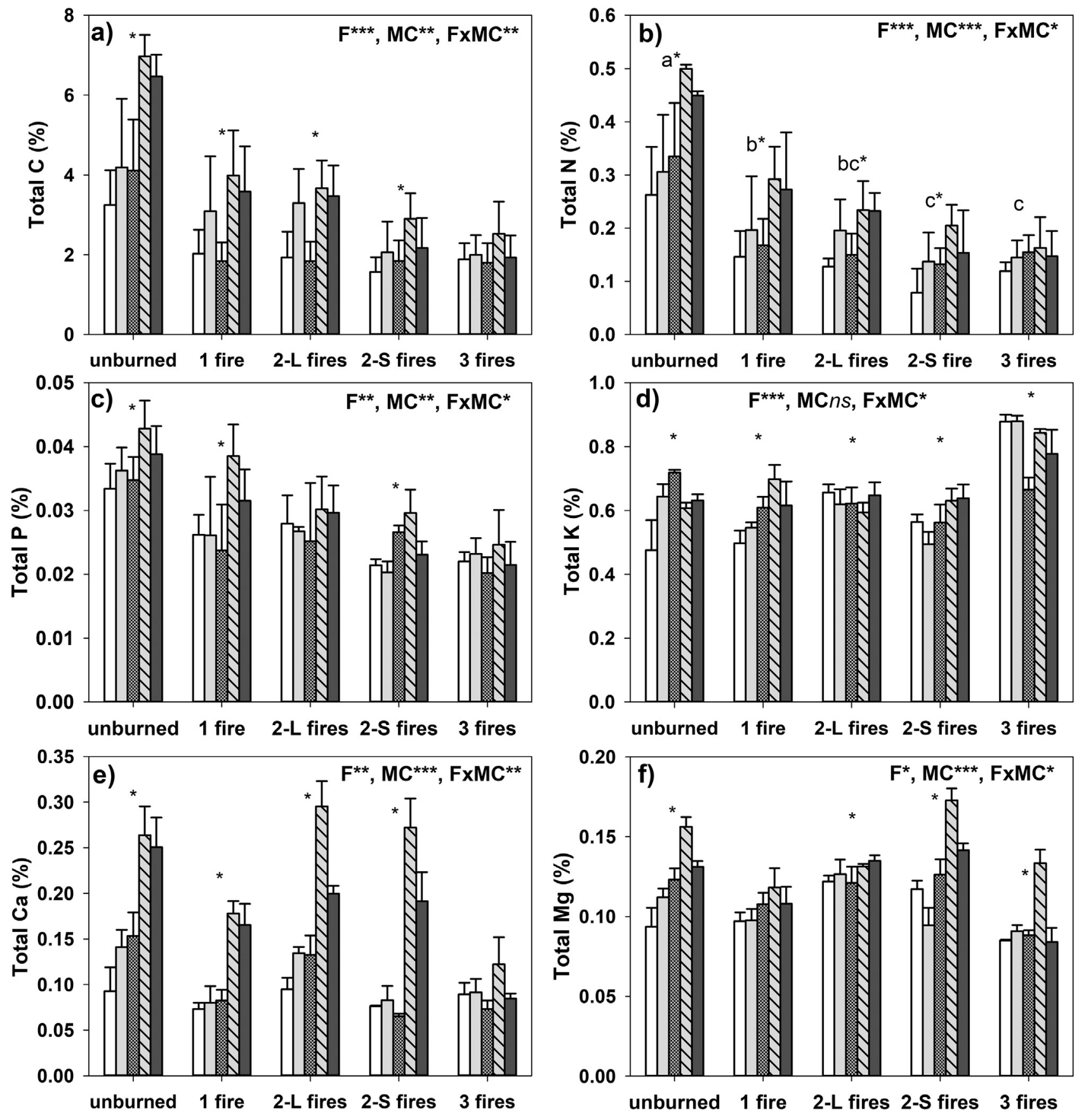

FIRE HISTORY

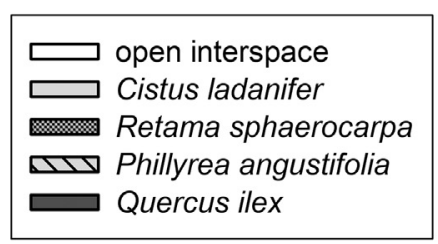

FIRE HISTORY

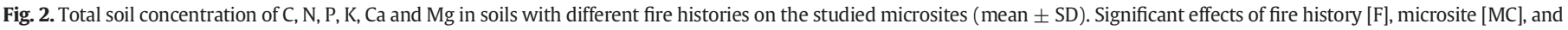

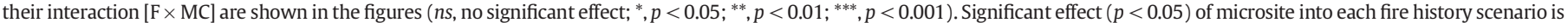
indicated by * over the bars.

sites (three fires), an increase in foliar P concentration was observed in $C$. ladanifer and $Q$. ilex. In sites affected by three fires a lower foliar $\mathrm{Ca}$ concentration was observed in $Q$. ilex.

The studied plant species were clearly differentiated according to their foliar N:P ratio. Q. ilex showed the highest values of foliar $\mathrm{N}: \mathrm{P}$ ratio and $P$. angustifolia and $C$. ladanifer the lowest. Only the leaves of $C$. ladanifer showed a significantly reduced $(p<0.05) \mathrm{N}$ :P ratio with increasing fire frequency (Fig. 7).

The effect of fire frequency on litter nutrient concentration was less consistent among the studied plant species (Table 3 ). High fire 

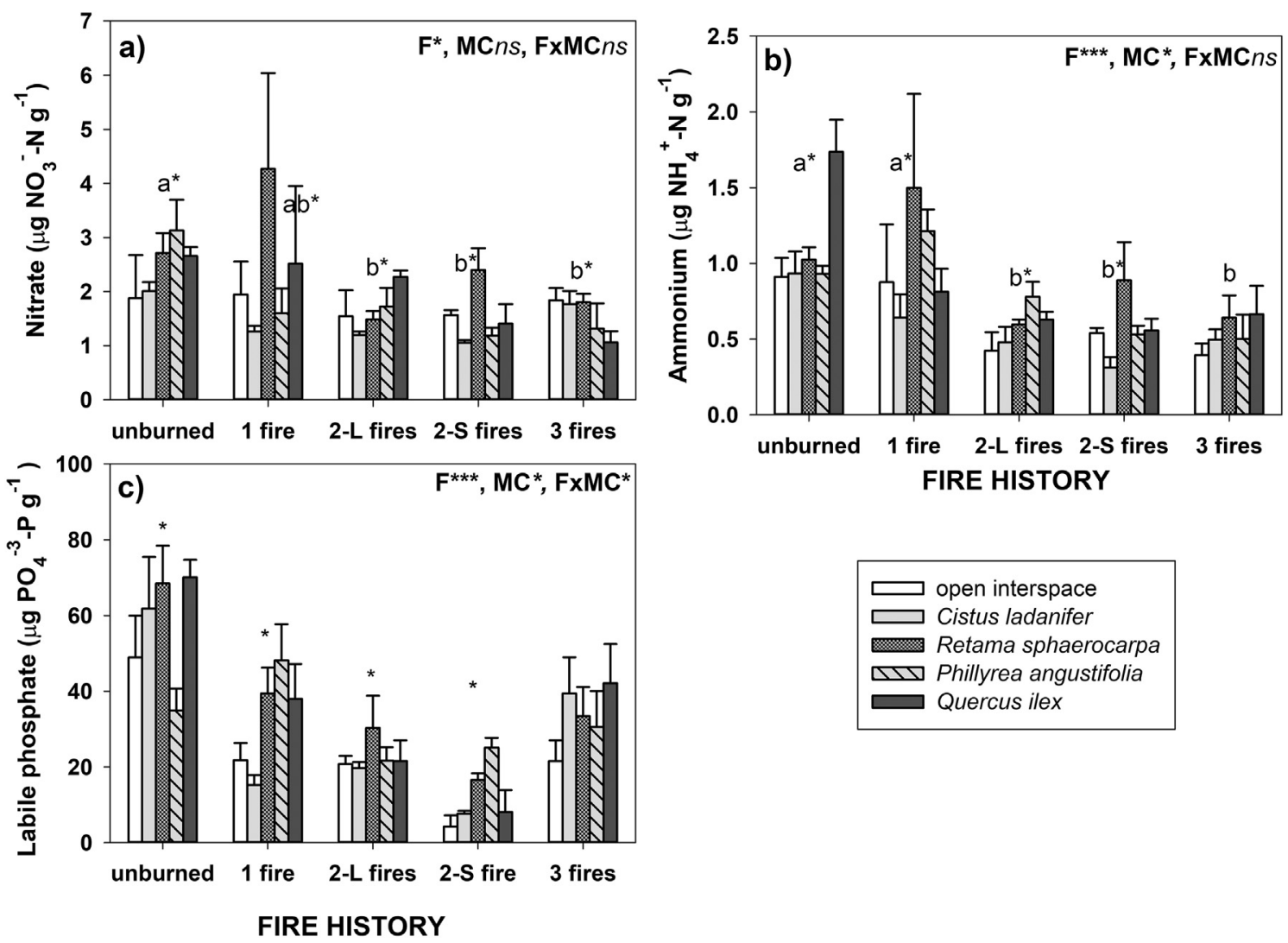

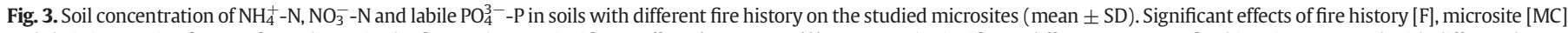

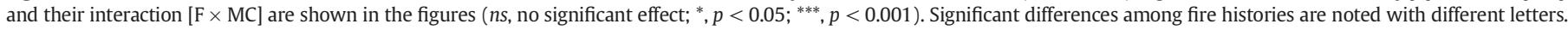
Significant effect $(p<0.05)$ of microsite into each fire history scenario is indicated by * over the bars.

frequency reduced $\mathrm{N}$ concentration in $\mathrm{Q}$. ilex litter, reduced $\mathrm{Ca}$ in C. ladanifer litter, and reduced Mg in R. sphaerocarpa litter $(p<0.05)$.

\section{Discussion}

Evaluating the consequences of increased fire frequency on soil properties has been a major topic of research in recent years (Mayor et al., 2016b; Pellegrini et al., 2018). Interest in this field has been driven by the fact that many regions in the world are seeing changes in their fire regimes with longer fire seasons and an increased frequency of large and high-severity fires (Pellegrini et al., 2018). Yet, most of the studies carried out have targeted soil as a single component of the ecosystem. Despite the possible limitations of our diachronic approach for assessing fire frequency effects, our results strongly support that high fire frequency, producing changes from a $Q$. ilex woodland to a shrubland, can increase the risk of reducing soil fertility under woody plant canopies. This could compromise the availability of some nutrients for the biota.

\subsection{Fertile island development under woody plant canopies in unburned soils}

According to our results, the presence of woody plants in unburned ecosystems tended to improve soil conditions underneath them, with the development of more fertile microsites and greater microbial functionality. The formation of these fertility islands is dependent of each plant species, with $Q$. ilex and P. angustifolia, both resprouters, presenting the highest soil fertility beneath their canopies. Similar findings have been previously described under plant canopies for other unburned arid and semiarid areas (Schlesinger et al., 1990; Titus et al.,
2002; Gómez-Rey et al., 2013). Plants have the capacity to change the soil mainly through the incorporation of SOM and nutrient cycling (Dahlgren et al., 1997). We found that the presence of woody plants (mainly P. angustifolia and Q. ilex) increased the amount of SOM underneath them compared to open interspace microsites. This result supports previous studies (Schade and Hobbie, 2005; Gómez-Rey et al., 2013). Nutrient distribution patterns observed in our study also confirmed that the vegetation canopy strongly modulates CEC and the cycles of many nutrients, probably associated with a higher SOM incorporation (Dahlgren et al., 1997). Dahlgren et al. (1997) and Titus et al. (2002) also reported higher CEC values and higher concentration of C, $\mathrm{N}, \mathrm{P}, \mathrm{K}, \mathrm{Ca}$ and $\mathrm{Mg}$ under Quercus sp. and other woody species canopies compared with levels in the interspaces. In general, total $\mathrm{N}, \mathrm{NH}_{4}^{+}-\mathrm{N}$ and $\mathrm{NO}_{3}^{-}-\mathrm{N}$ were higher under woody plant canopies, mainly $P$. angustifolia and $Q$. ilex, corroborating studies of a higher concentration of available inorganic N forms in soils underneath Q. ilex (Gallardo et al., 2000) or other Mediterranean woody plants as Quercus suber L. (Gómez-Rey et al., 2013). In contrast, C. ladanifer (seeder) showed the lowest $\mathrm{N}$ availability beneath its canopies (about $40 \%$ less available $\mathrm{NO}_{3}^{-}-\mathrm{N}$ than $P$. angustifolia). This could be due, among other factors, to a reduction of nitrification associated with the presence of phenolic compounds in soils underneath this species (Mariscal-Sancho et al., 2010). It has been reported that phenolic compounds decrease soil $\mathrm{N}$ availability by (i) forming complexes with proteins and hampering SOM mineralization; (ii) increasing microbial $\mathrm{N}$ immobilization; (iii) inhibiting nitrification and (iv) inhibiting fungal respiration (Castells et al., 2004). Soil enzyme activity was clearly enhanced by woody plant cover. This was also seen in Mediterranean soils studied by Mariscal-Sancho et al. (2010), Gómez-Rey et al. (2013) and Mayor et al. (2016b). LópezPoma and Bautista (2014) suggested that this positive effect of woody 

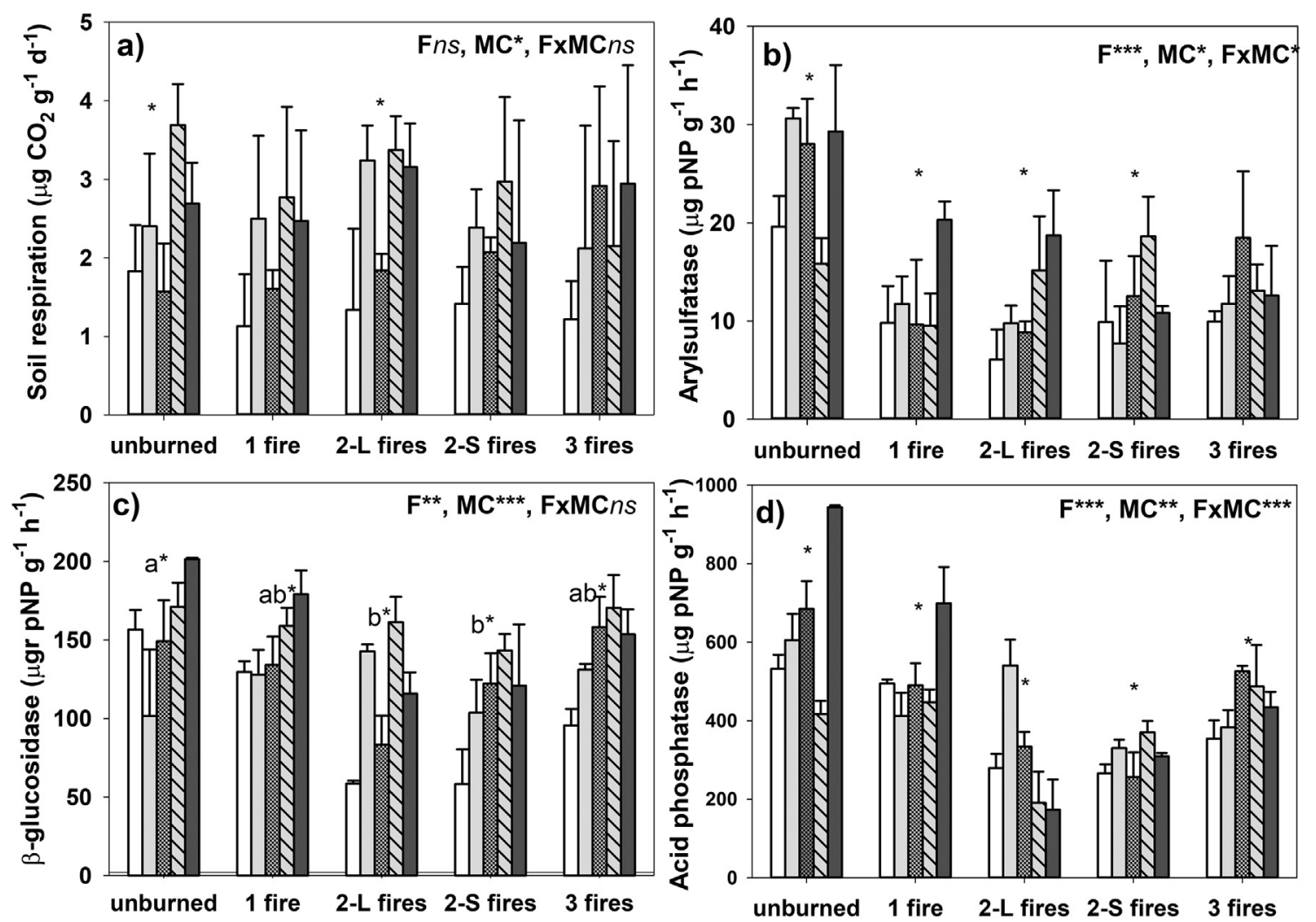

FIRE HISTORY

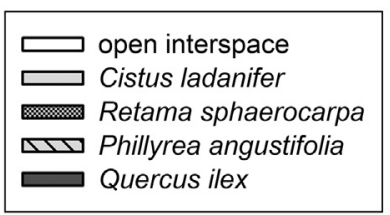

FIRE HISTORY

Fig. 4. Soil basal respiration rate and enzyme activity in soils with different fire histories from the studied microsites (mean \pm SD). Significant effects of fire history [F], microsite [MC], and their interaction $[\mathrm{F} \times \mathrm{MC}]$ are shown in the figures ( $n s$, no significant effect; ${ }^{*}, p<0.05 ;{ }^{* *}, p<0.01 ;{ }^{* * *}, p<0.001$ ). Significant differences among fire histories are noted with different letters. Significant effect $(p<0.05)$ of microsite into each fire history scenario is indicated by * over the bars.

plant canopies on soil enzyme activity may be due mainly to SOM accumulation beneath the canopies. SOM contributes to physical stabilization of enzymes and constitute their main substrate (Sinsabaugh, 1994). Similarly, a higher soil respiration rate underneath woody plant canopies was observed. This finding was consistent with previous studies that attributed this to a higher SOM availability, i.e. high SOM was related to high soil respiration rate (McCulley et al., 2004; Gómez-Rey et al., 2013).

The observed differences among woody plant species in the development of fertile islands and associated increased microbial activity
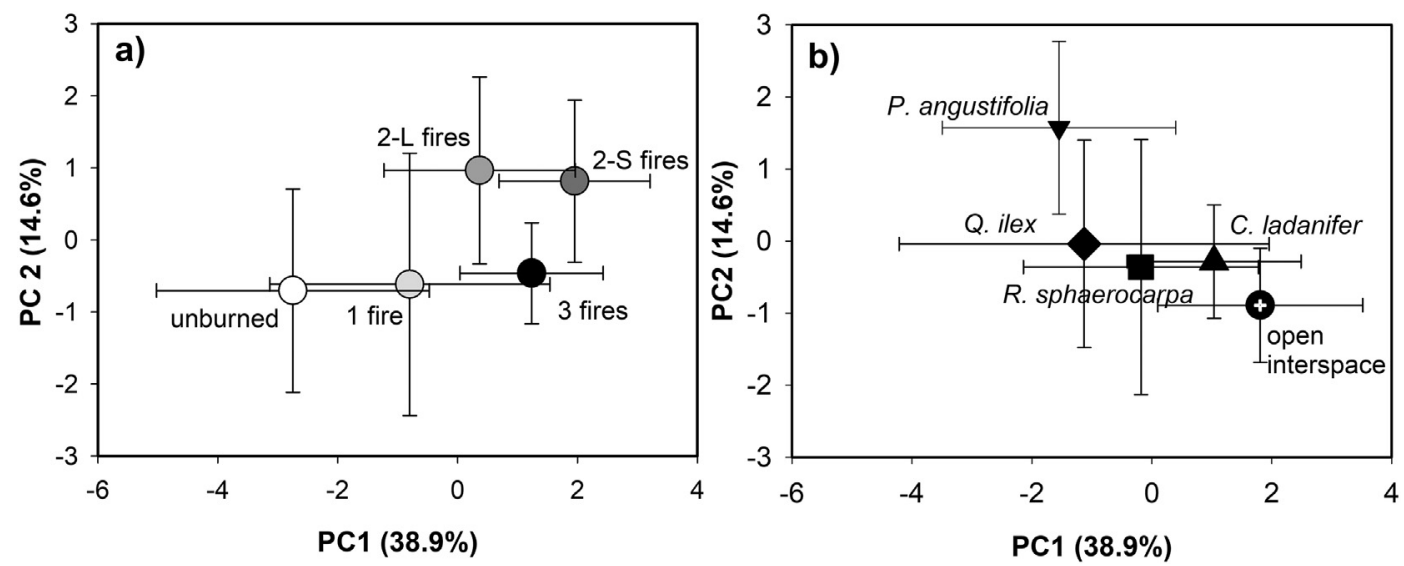

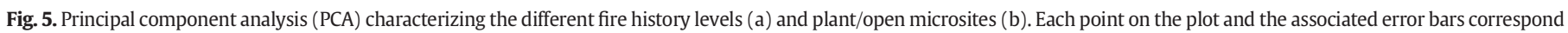
to the mean and the SD. 
Table 1

Loading factors and total variance (\%) in the first two principal components (PC1 and PC2) resulting from principal components analysis (PCA) for the studied soil variables.

\begin{tabular}{lcc}
\hline & PC1 (38.9\%) & PC2 (14.6\%) \\
\hline Organic matter & $\mathbf{- 0 . 8 9}$ & 0.01 \\
$\mathrm{pH}$ & -0.06 & $\mathbf{0 . 7 8}$ \\
Respiration & -0.21 & 0.15 \\
Acid phosphatase & $\mathbf{- 0 . 6 5}$ & -0.41 \\
$\beta$-Glucosidase & $\mathbf{- 0 . 6 2}$ & 0.14 \\
Arylsulfatase & 0.10 & $\mathbf{0 . 5 1}$ \\
$\mathrm{NH}_{4}^{+}-\mathrm{N}$ & $\mathbf{- 0 . 6 7}$ & -0.48 \\
$\mathrm{NO}_{3}^{-}-\mathrm{N}$ & -0.43 & -0.43 \\
$\mathrm{PO}_{4}^{3-}-\mathrm{P}$ & $\mathbf{- 0 . 7 8}$ & -0.29 \\
Total N & $\mathbf{- 0 . 9 4}$ & -0.01 \\
Total C & $\mathbf{- 0 . 9 4}$ & 0.08 \\
Total P & $\mathbf{- 0 . 8 7}$ & 0.09 \\
Total Ca & $\mathbf{- 0 . 7 4}$ & 0.49 \\
Total K & $\mathbf{- 0 . 0 1}$ & -0.01 \\
Total Mg & $\mathbf{- 0 . 6 3}$ & 0.29 \\
CEC & -0.49 & $\mathbf{0 . 5 3}$ \\
\hline
\end{tabular}

Bond numbers denote significant correlation $(p<0.05)$

(basal respiration rate and enzyme activities) are due to both abiotic and biotic factors (e.g. SOM quantity and quality or microbial biomass). Some of the specific mechanisms involved in the development of fertile islands have been previously mentioned in the discussion (e.g. differential mineralization rates of SOM). Litter, being the main source of SOM, is one feature that differentiates plant species. This factor is important for both the differential amount and chemical composition of SOM contributed to the soil by different plant species (Aponte et al., 2013).

\subsection{Fire history effect on soil fertile island development under woody plant canopies}

This study demonstrates that for some soil properties the microsite effect was fire history dependent. For these soil properties, the positive effect on soil fertility under some woody plants canopies (mainly P. angustifolia and Q. ilex) was evident even in soils affected by one or two fires. However, the most relevant result of our study is that in areas with higher fire frequency (three fires during the study period) this positive effect on soil fertility under some woody plant canopies tended to disappear. This is the case for soil properties such as SOM, $\mathrm{CEC}, \mathrm{pH}$, total $\mathrm{C}, \mathrm{N}, \mathrm{P}, \mathrm{Ca}$ and $\mathrm{Mg}$ concentration, $\mathrm{PO}_{4}^{3-}-\mathrm{P}$, arylsulfatase and acid phosphatase activities.

We found that frequent fires (2-S and 3 fires) reduced the incorporation of new SOM under the studied woody plants. There are several factors that could modulate SOM accumulation under woody plant canopies in reburned soils. Eugenio et al. (2006) associated the medium- to long-term negative effects of high fire frequency on the amount of SOM with a cumulative reduction of soil organic horizons since reburning occurs before the organic horizon can completely recover. The reduced SOM accumulation under plant canopies with increasing fire frequency may also be linked to a smaller biomass of woody plants as fire recurrence increases (Ferran et al., 2005; Santana et al., 2013). Such a delay in the recovery of the woody plant canopy in frequently burned sites, combined with a low recovery of soil, could promote soil erosion, potentially leading to a greater loss of SOM from the system (Mayor et al., 2016b). This factor should be considered for our study sites due to steep slopes that favour runoff and erosion processes. Other factors such as the amount of belowground detrital material incorporated into the burned soil (i.e. dead roots or microorganism) may also influence the SOM pool (Cleary et al., 2010). Nevertheless, the impact of these factors is unknown in our study. Our results showed that burned soils with low fire frequency ( 1 or 2-L fires) were characterized by a significant microsite effect concerning soil CEC, $\mathrm{pH}$ value, total nutrients and $\mathrm{PO}_{4}^{3-}$-P. Despite burning, soil properties remained elevated under woody plant cover compared to open interspaces. It is widely accepted that higher plant biomass promotes a higher fire severity in microsites under woody plant canopies (Rau et al., 2007; Blank et al., 2017). In contrast, open interspaces remained unchanged regarding their soil nutrient availability, probably due to a lower soil heating during fire, associated with factors such as a lower plant biomass (Santana et al., 2011). Immediately after fire, and mostly under woody plant canopy microsites, wildfire could increase the amount of nutrients in the soil due to ash incorporation (DeBano and Conrad, 1978; Bodí et al., 2014; Mayor et al., 2016b). After fire, much of the ash is prone to be redistributed or removed from the burned site by wind and surface runoff (Bodí et al., 2014; Caon et al., 2014). However, surviving plants are able to take up nutrients from the fire-affected soil, and maintain the nutrient cycle in the soil-plant system via litter and decomposition after the fire (Caldwell, 1994). It should be remembered that canopy throughfall and stemflow can also contribute nutrients to soil surface fertilization (Bellot et al., 1999). Additionally, woody plant canopy could reduce potential leaching and soil erosion rates, for example, through mechanisms associated with water canopy interception, increased transpiration, deeper roots or a higher infiltration rate (Dahlgren et al., 1997). In contrast, a high fire frequency appears to lead to a reduction or disappearance of differences among microsites in terms of total soil nutrient content and $\mathrm{PO}_{4}^{3-}$-P levels. The reduced incorporation of new SOM under woody plant canopy in soils affected by high fire frequency could be the primary reason for the similarity among microsites with regard to $\mathrm{CEC}$, total nutrients and $\mathrm{PO}_{4}^{3-}{ }^{-}$-P levels (Ferran et al., 2005; Guénon et al., 2013; Mayor et al., 2016a). Sankey et al. (2012) also suggested that increased fire frequency implies that microsite soil properties are afforded less time to recover between fires, and the enrichment of soil fertility under shrub canopies are reduced by more frequent erosion. Similarly, with low fire frequency, acid phosphatase and arylsulfatase activities showed higher values under woody plant canopy than in the open interspaces. Similar results were described by López-Poma and Bautista (2014) and Mayor et al. (2016a) in fire-prone Mediterranean shrublands. However, we observed that with high fire frequency, the significant differences in soil enzyme activity among microsites tended to be minimized. This could be attributed to the effects of a lower biomass input to soils (e.g. litter) in terms of enzyme substrate and/or to the effects of the modification of properties involved in the regulation of enzyme activity (e.g., microbial biomass) (Burns and Dick, 2002), after recurrent fire events. It could also be due to differential post-fire feedback between the vegetation spatial structure, the surface flow of water and sediment, and soil surface quality (Mayor et al., 2016a). This reduction in enzyme activity under woody plant canopies in frequently burned soils could influence the longer-term availability of soil nutrients, compromising the recovery of the plant community.

Microsite effects were not always fire-history dependent for all studied soil properties. Soil properties such as $\beta$-glucosidase activity decreased with increasing fire frequency, but their spatial variability among microsites was maintained along all fire frequency scenarios. This is in line with a report by López-Poma and Bautista, (2014) describing the high resilience of this enzyme activity to fire. In their study no significant differences in resilience were observed among four types of shrubland microsites. The different response of the studied enzymes to the interaction between microsite and fire-history depend on their predominant control mechanism and cannot be elucidated from our research.

Despite the fact that the microsite effect was not fire-history dependent for available mineral $\mathrm{N}$, we observed that repeated fires led to a substantial depletion of available inorganic forms of $\mathrm{N}$ in soils. A temporary enhanced mineral $\mathrm{N}$ availability is widely described immediately after fire (Carreira et al., 1994; Caon et al., 2014). Nevertheless, this reduction in available inorganic forms of $\mathrm{N}$ may be attributed to repetitive losses due to volatilization, runoff, leaching and soil erosion occurring due to frequent fires, which were not compensated through $\mathrm{N}_{2}$ fixation or SOM incorporation to soils and further mineralization (Ferran et al., 

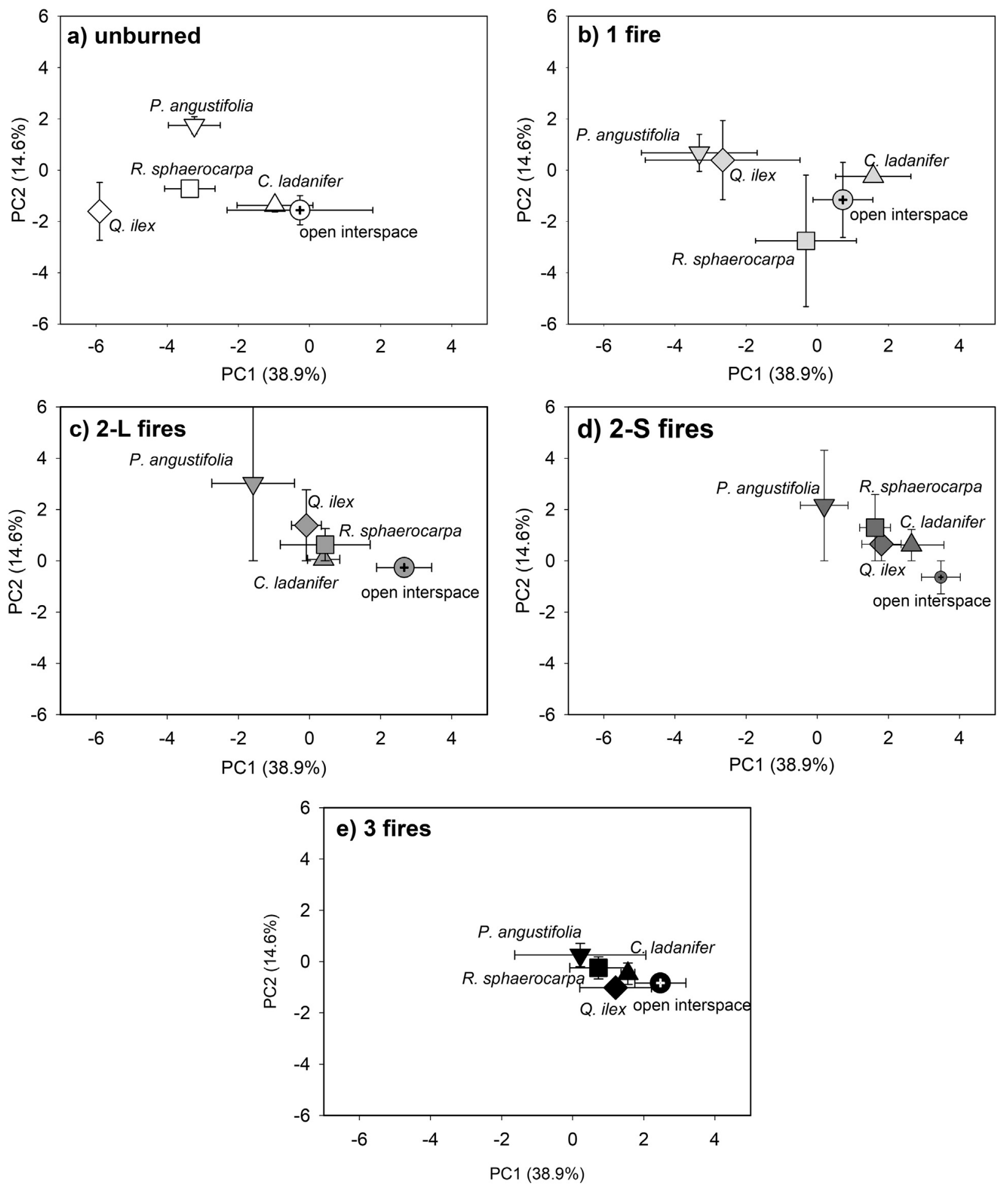

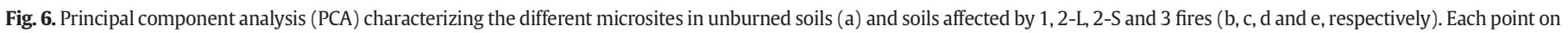
the plot and the associated error bars correspond to the mean and the SD.

2005; Caon et al., 2014). Low $\mathrm{NH}_{4}^{+}-\mathrm{N}$ and $\mathrm{NO}_{3}^{-}-\mathrm{N}$ concentrations limit mineral $\mathrm{N}$ availability to plants playing an important role in post-fire regeneration of the plant community. As previously mentioned, available inorganic forms of $\mathrm{N}$ increased under woody plant canopies. In burned plots, soils under $R$. sphaerocarpa (Leguminosae) canopy tended to show higher values of $\mathrm{NH}_{4}^{+}-\mathrm{N}$ and $\mathrm{NO}_{3}^{-}-\mathrm{N}$, probably caused by active $\mathrm{N}$ fixation associated with this plant species (Rodríguez-Echeverría and Pérez-Fernández, 2003). This finding highlights the important role of legumes in maintaining the $\mathrm{N}$ cycle in burned ecosystems, facilitating their post-fire recovery.

In contrast, soil basal respiration rate ( $\mathrm{C}$ mineralization) did not show significant differences due to fire frequency, and the observed positive effect of plant cover in unburned soils was not generally detected in burned soils. Soil respiration is dependent of factors as the lability of SOM, soil temperature and moisture (Curiel et al., 2007). Although we found that SOM decreased with increasing fire frequency 
Table 2

Total foliar nutrient concentration of the studied plant species. Different letters denote significant differences in the concentration of the element among fire histories $(p<0.05)$

\begin{tabular}{|c|c|c|c|c|c|c|}
\hline Fire history & $\mathrm{C}(\%)$ & $\mathrm{N}(\%)$ & $\mathrm{P}(\%)$ & $\mathrm{K}(\%)$ & $\mathrm{Ca}(\%)$ & $\operatorname{Mg}(\%)$ \\
\hline \multicolumn{7}{|c|}{ Cistus ladanifer } \\
\hline Unburned & $48.83(1.93)$ & $1.39(0.01) \mathrm{a}$ & $0.09(0.01) \mathrm{a}$ & $0.69(0.17)$ & $0.83(0.15)$ & $0.12(0.05)$ \\
\hline 1 fire & $47.73(1.82)$ & $1.34(0.02) b$ & $0.09(0.01) \mathrm{a}$ & $0.67(0.15)$ & $0.86(0.22)$ & $0.14(0.09)$ \\
\hline 2-L fires & $49.05(1.50)$ & $1.36(0.05) a b$ & $0.11(0.01) a b$ & $0.62(0.12)$ & $0.79(0.19)$ & $0.15(0.11)$ \\
\hline 2-S fires & $48.76(1.67)$ & $1.33(0.01) b$ & $0.12(0.01) b$ & $0.59(0.11)$ & $0.81(0.13)$ & $0.12(0.06)$ \\
\hline 3 fires & $47.60(0.94)$ & $1.26(0.09) \mathrm{b}$ & $0.14(0.02) \mathrm{b}$ & $0.75(0.15)$ & $0.68(0.11)$ & $0.11(0.04)$ \\
\hline \multicolumn{7}{|c|}{ Retama sphaerocarpa } \\
\hline Unburned & $46.68(0.59)$ & $1.84(0.19)$ & $0.08(0.02)$ & $0.56(0.13)$ & $1.10(0.44)$ & $0.21(0.09)$ \\
\hline 1 fire & $48.04(1.90)$ & $2.09(0.09)$ & $0.07(0.01)$ & $0.67(0.09)$ & $0.86(0.11)$ & $0.23(0.09)$ \\
\hline 2-L fires & $47.09(0.89)$ & $1.98(0.05)$ & $0.07(0.01)$ & $0.65(0.11)$ & $0.84(0.09)$ & $0.15(0.02)$ \\
\hline 2-S fires & $47.61(1.12)$ & $1.88(0.04)$ & $0.09(0.01)$ & $0.59(0.09)$ & $0.79(0.07)$ & $0.11(0.06)$ \\
\hline 3 fires & $46.98(1.08)$ & $1.79(0.12)$ & $0.08(0.01)$ & $0.71(0.15)$ & $0.73(0.15)$ & $0.10(0.05)$ \\
\hline \multicolumn{7}{|c|}{ Phillyrea angustifolia } \\
\hline Unburned & $50.62(1.63)$ & $1.05(0.05) \mathrm{a}$ & $0.08(0.05)$ & $0.69(0.02)$ & $0.82(0.12)$ & $0.16(0.05)$ \\
\hline 1 fire & $50.69(1.08)$ & $1.13(0.08) \mathrm{a}$ & $0.09(0.01)$ & $0.59(0.10)$ & $0.82(0.09)$ & $0.15(0.05)$ \\
\hline 2-L fires & $51.06(0.87)$ & $1.01(0.05) a b$ & $0.09(0.01)$ & $0.63(0.12)$ & $0.79(0.11)$ & $0.13(0.04)$ \\
\hline 2-S fires & $49.83(0.97)$ & $0.98(0.04) a b$ & $0.07(0.01)$ & $0.64(0.09)$ & $0.75(0.08)$ & $0.15(0.06)$ \\
\hline 3 fires & $49.98(1.23)$ & $0.97(0.01) \mathrm{b}$ & $0.05(0.02)$ & $0.75(0.06)$ & $0.67(0.07)$ & $0.12(0.02)$ \\
\hline \multicolumn{7}{|l|}{ Quercus ilex } \\
\hline Unburned & $48.45(0.66)$ & $1.22(0.08) \mathrm{a}$ & $0.02(0.00) \mathrm{a}$ & $0.25(0.05)$ & $0.76(0.02) \mathrm{a}$ & $0.10(0.01)$ \\
\hline 1 fire & $48.09(1.08)$ & $1.19(0.06) a b$ & $0.02(0.01) a b$ & $0.29(0.11)$ & $0.68(0.11) a b$ & $0.12(0.03)$ \\
\hline 2-L fires & $49.18(0.58)$ & $1.08(0.04) \mathrm{b}$ & $0.02(0.01) a b$ & $0.27(0.09)$ & $0.71(0.09) a b$ & $0.11(0.05)$ \\
\hline 2-S fires & $47.67(0.87)$ & $0.91(0.05) \mathrm{c}$ & $0.03(0.01) a b$ & $0.26(0.11)$ & $0.62(0.12) a b$ & $0.10(0.01)$ \\
\hline 3 fires & $47.98(1.28)$ & $0.79(0.21) \mathrm{d}$ & $0.04(0.01) b$ & $0.31(0.08)$ & $0.59(0.10) \mathrm{b}$ & $0.08(0.01)$ \\
\hline
\end{tabular}
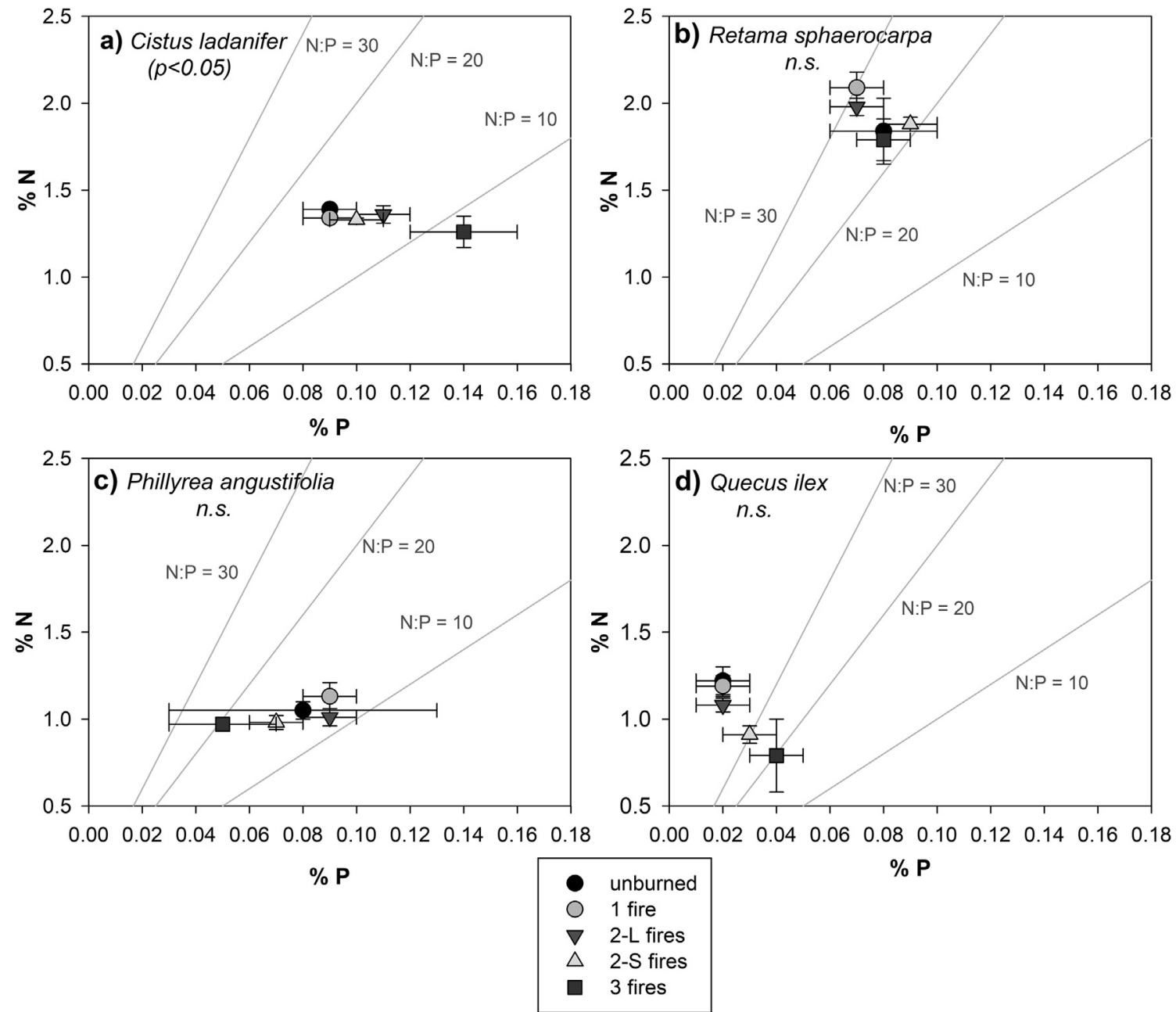

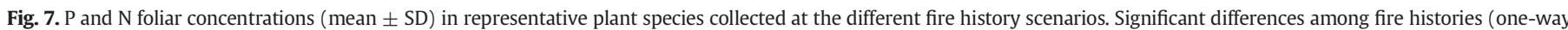
ANOVA, $\alpha=0.05$ ) are noted for each plant species, "ns" denote not significant effect. 
Table 3

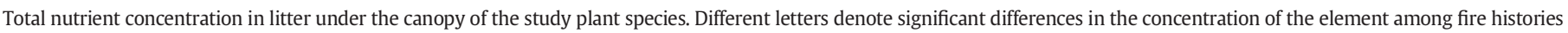
$(p<0.05)$.

\begin{tabular}{|c|c|c|c|c|c|c|}
\hline Fire history & $C(\%)$ & $\mathrm{N}(\%)$ & $\mathrm{P}(\%)$ & $\mathrm{K}(\%)$ & $\mathrm{Ca}(\%)$ & $\operatorname{Mg}(\%)$ \\
\hline \multicolumn{7}{|c|}{ Cistus ladanifer } \\
\hline Unburned & $38.72(1.69)$ & $0.72(0.18)$ & $0.03(0.00)$ & $0.69(0.02)$ & $0.86(0.04) \mathrm{a}$ & $0.09(0.03)$ \\
\hline 1 fire & $38.09(1.66)$ & $0.68(0.03)$ & $0.04(0.01)$ & $0.67(0.15)$ & $0.81(0.22) \mathrm{ab}$ & $0.10(0.01)$ \\
\hline 2-L fires & $37.64(0.84)$ & $0.69(0.05)$ & $0.04(0.01)$ & $0.62(0.12)$ & $0.79(0.19) \mathrm{ab}$ & $0.09(0.01)$ \\
\hline 2-S fires & $38.01(1.12)$ & $0.68(0.01)$ & $0.03(0.01)$ & $0.59(0.11)$ & $0.81(0.13) a b$ & $0.08(0.01)$ \\
\hline 3 fires & $36.57(0.79)$ & $0.67(0.09)$ & $0.03(0.00)$ & $0.75(0.15)$ & $0.70(0.11) b$ & $0.07(0.02)$ \\
\hline \multicolumn{7}{|c|}{ Retama sphaerocarpa } \\
\hline Unburned & $46.63(0.57)$ & $1.40(0.16)$ & $0.03(0.01)$ & $0.60(0.01)$ & $0.90(0.31)$ & $0.29(0.11) \mathrm{a}$ \\
\hline 1 fire & $46.07(1.70)$ & $1.41(0.05)$ & $0.04(0.01)$ & $0.67(0.09)$ & $0.95(0.13)$ & $0.24(0.09) \mathrm{a}$ \\
\hline 2-L fires & $46.16(0.89)$ & $1.39(0.09)$ & $0.03(0.01)$ & $0.65(0.11)$ & $0.90(0.11)$ & $0.14(0.05) \mathrm{ab}$ \\
\hline 2-S fires & $45.36(1.12)$ & $1.39(0.08)$ & $0.03(0.00)$ & $0.59(0.09)$ & $0.83(0.21)$ & $0.12(0.09) \mathrm{ab}$ \\
\hline 3 fires & $45.01(1.08)$ & $1.38(0.12)$ & $0.02(0.01)$ & $0.71(0.15)$ & $0.71(0.15)$ & $0.12(0.02) \mathrm{b}$ \\
\hline \multicolumn{7}{|c|}{ Phillyrea angustifolia } \\
\hline Unburned & $42.52(1.27)$ & $0.74(0.02)$ & $0.05(0.02)$ & $0.76(0.36)$ & $0.76(0.22)$ & $0.15(0.05)$ \\
\hline 1 fire & $43.19(1.01)$ & $0.74(0.05)$ & $0.04(0.01)$ & $0.69(0.11)$ & $0.72(0.08)$ & $0.15(0.05)$ \\
\hline 2-L fires & $42.09(0.87)$ & $0.73(0.04)$ & $0.04(0.01)$ & $0.58(0.13)$ & $0.69(0.07)$ & $0.13(0.04)$ \\
\hline 2-S fires & $41.97(0.97)$ & $0.72(0.01)$ & $0.03(0.01)$ & $0.57(0.25)$ & $0.64(0.06)$ & $0.15(0.06)$ \\
\hline 3 fires & $40.36(1.23)$ & $0.69(0.03)$ & $0.03(0.01)$ & $0.60(0.09)$ & $0.69(0.05)$ & $0.12(0.02)$ \\
\hline \multicolumn{7}{|l|}{ Quercus ilex } \\
\hline Unburned & $44.63(0.81)$ & $1.18(0.06) \mathrm{a}$ & $0.04(0.01)$ & $0.13(0.02)$ & $0.78(0.55)$ & $0.08(0.04)$ \\
\hline 1 fire & $43.97(1.08)$ & $1.19(0.04) \mathrm{a}$ & $0.03(0.01)$ & $0.15(0.01)$ & $0.69(0.13)$ & $0.10(0.03)$ \\
\hline 2-L fires & $43.82(0.58)$ & $0.98(0.05) \mathrm{b}$ & $0.02(0.00)$ & $0.14(0.05)$ & $0.72(0.12)$ & $0.11(0.05)$ \\
\hline $2-S$ fires & $42.87(0.89)$ & $0.90(0.15) \mathrm{ab}$ & $0.02(0.01)$ & $0.13(0.01)$ & $0.66(0.10)$ & $0.10(0.01)$ \\
\hline 3 fires & $43.36(1.28)$ & $0.87(0.09) \mathrm{c}$ & $0.02(0.01)$ & $0.12(0.02)$ & $0.53(0.08)$ & $0.08(0.01)$ \\
\hline
\end{tabular}

we did not observed an associated decrease in soil respiration rate. This unexpected discrepancy could be related to hydric stress of the soil during the summer, when soil samples were collected, since at this time a reduction in microbial biomass and activity is generally observed even when respiration was evaluated under laboratory conditions (Hinojosa et al., 2016). This hypothesis is supported by the general low values for soil respiration rates recorded in our study. Different authors have shown that low soil moisture generates low soil respiration values that could masks the possible effects associated with other treatments, such as microsite (Davidson et al., 1998; Hinojosa et al., 2016).

Despite the uneven ratio of seeders and resprouters considered in our study, taken together our results indicate a positive influence of woody plant cover, mainly resprouter species, on soil fertility indicators when fire frequency is low. Resprouters are benefited for their faster post-fire recovery, due to their ability to rapidly mobilize their underground reserves, and older age of resprouter patches after fire (Whelan, 1995). Nevertheless, as fire frequency increases the fertility islands disappear. Thus, high frequency fire trend to homogenize the spatial variability of soil, which could delay the recovery of post fire ecosystem functionality. These fertility islands under plant canopy could act not only as biogeochemical hot spots, that is, patches that show disproportionately high reaction rates relative to the surrounding matrix (McClain et al., 2003), but also as important areas for seedling establishment and plant interactions (Aguiar and Sala, 1999).

\subsection{Fire frequency effect on plant leaves and litter nutrients}

Leaf nutrient concentration observed here were similar to those reported in other studies in Mediterranean ecosystems for C. ladanifer (Nuñez-Olivera et al., 1996), R. sphaerocarpa (Villar-Salvador et al., 2008), P. angustifolia (Maisto et al., 2011) and Q. ilex (Sabaté et al., 1995). Leaves of $R$. sphaerocarpa presented the highest $\mathrm{N}: \mathrm{P}$ total ratio supporting the idea that $\mathrm{N}_{2}$-fixers often have higher foliar $\mathrm{N}: \mathrm{P}$ ratios than co-occurring non-fixers (Güsewell et al., 2003). Despite having the lowest nutrient concentrations in leaves, $Q$. ilex showed a high foliar $\mathrm{N}: \mathrm{P}$ ratio. This characteristic is present in many plants that live under nutrient-limited conditions, have a long-life span (Wright and
Westoby, 2003) and have efficient nutrient reabsorption prior to leaf abscission (Aerts and Chapin, 2000).

In our study, fire frequency tended to unbalance the concentration of certain nutrients within the plant. The extent to which fire modifies the concentration of specific nutrients in post-burn vegetation differs among the nutrients in question (Van de Vijver et al., 1999). In our study, the decrease of leaf $\mathrm{N}$ content with increasing fire frequency (in all plant species, except $R$. sphaerocarpa), could be due to the reduction of soil total and available forms of inorganic $\mathrm{N}\left(\mathrm{NH}_{4}^{+}-\mathrm{N}\right.$ and $\left.\mathrm{NO}_{3}^{-}-\mathrm{N}\right)$ in these soils, as formerly discussed. However, $\mathrm{P}$ concentration in leaves of some plants (C. ladanifer and $Q$. ilex) increased with fire frequency, despite total and available $P$ in these soils being lower than in unburned ones. These enhanced $P$ concentrations in post-fire regrowth may be due to the reduction in the soil N:P ratio of available nutrient pools at the burned sites. Güsewell (2004) pointed out that foliar N:P ratios are largely determined by the relative supplies of $\mathrm{N}$ and $\mathrm{P}$ from soil. According to Vitousek and Howarth (1991), any ecosystem disturbance should affect $\mathrm{N}$ retention mechanisms more than $\mathrm{P}$ retention mechanisms, because $\mathrm{N}$ is retained in the ecosystem mainly by biological processes, whilst $\mathrm{P}$ is retained by both biological and geochemical retention mechanisms.

The leaf N:P ratio tended to decrease with increasing fire frequency, but this tendency was significant only for $C$. ladanifer. This finding is supported by Toberman et al. (2014) who showed reductions in the leaf $\mathrm{N}$ :P ratio in eucalypt forest ecosystems that had suffered recurrent fires. The greater effect of fire recurrence reported in the study by Toberman et al. (2014) could be due to the fact that they evaluated a higher fire frequency (prescribed burning once every two or four years during a 48 year period). Thus, our analyses indicate that patterns in plant leaf $\mathrm{N}, \mathrm{P}$, and $\mathrm{N}: \mathrm{P}$ ratio in relation to fire frequency cannot be generalized across all plant species. Not all the studied plant species are equally adapted to nutrient losses caused by recurring fire. This differential response of plant chemistry to fire frequency could lead to changes in the plant community and further alterations in ecosystem functionality.

In general, high fire frequency tended to cause a marginal decrease in nutrient concentration in litter. This trend was significant in only a 
few specific cases (Ca for C. ladanifer, $\mathrm{Mg}$ for $R$. sphaerocarpa and $\mathrm{N}$ for Q. ilex). The shifts in leaf nutrient stoichiometry are not directly related to litter stoichiometry. This fact could be due to stoichiometric changes in corresponding living plant biomass and/or to stoichiometric adjustment in the reabsorption of nutrients during leaf senescence (Wright and Westoby, 2003; Toberman et al., 2014). Future studies of plant tissue stoichiometry, reabsorption and decomposition are needed to evaluate these alternatives in post-fire scenarios (Manzoni et al., 2010; Toberman et al., 2014).

Whilst soil properties and fire may modify the species and functional traits present on plant communities (Müller et al., 2007), plants can also alter soil properties (Fornara and Tilman, 2008). The observed effect of increased fire frequency on the nutrient content of plant leaf tissue and litter may influence other components of an ecosystem apart from soil fertility, such as invertebrates, microorganism or herbivores, and the processes that they regulate (Güsewell and Gessner, 2009; Butler et al., 2019). These areas are currently unexplored.

Our findings underline the importance of fire frequency when dealing with soil and plant interaction in Mediterranean-type ecosystems. The plant-soil interphase presents wide vulnerability to recurrent fire events. Thus, under future climate change scenarios and associated changes in fire activity, adaptative and sustainable forest management strategies are needed in order to prevent fire recurrence and restore the historic fire intervals of the ecosystems (Francos et al., 2020). This aspect is crucial in arid and semiarid regions with fire-prone habitats and vulnerable biogeochemical soil stability.

In relation to post-fire management, the retention of nutrients in soils it is especially important after a high fire frequency scenario. It is important to stabilize the burnt site by applying post-fire measures aiming to limit for example soil erosion or surface runoff. Thus, surviving plants or new established individuals on the burned area will find higher soil resources, but also higher small-scale heterogeneity, which can have a large impact on the performance of individual plants on individual plants, on the interactions between plants, on plant populations and on plant communities (Hutchings et al., 2003). Post-fire restoration management should consider also promoting the presence of resprouters, which conferred more resistance and resilience to soil fertility degradation (López-Poma and Bautista, 2014).

\section{Conclusions}

The effect of increasing fire frequency in Mediterranean ecosystems is an issue that deserves to be investigated due to the increasing fire danger caused by climate change and land abandonment. However, very little information is available about the effect of fire history on the role of woody plant species in maintaining soil fertility beneath their canopies.

Our study shows that soils are more fertile under woody plant canopies than in open interspaces, mainly under resprouter species. This pattern remains even in a natural fire regime leading to a change from Q. ilex woodland to shrubland. However, this positive effect of woody plants in soil fertility decreased as fire frequency increased. This fact could influence the longer-term availability of soil nutrients, as demonstrated by the imbalance between $\mathrm{N}$ and $\mathrm{P}$ observed in the leaf tissue of some plant species. Thus, in the long term, these alterations in spatial heterogeneity of soil resources induced by different plant species might modify the coexistence of species, compromising the resilience of these fire-prone ecosystems, which should be considered for postfire land managers.

Our study provides evidence that future alterations in fire regime due to increased fire frequency could interact with plant canopy microsites in Mediterranean ecosystems to shift nutrient cycling and soil-plant feedbacks. In addition to fire frequency, the effect of other components of a fire regime (i.e., fire severity, seasonality), and the interactions with topography, on soil-plant nutrient feedbacks in the heterogeneous microsites existing in these open ecosystems is something that merits further investigation.

\section{CRediT authorship contribution statement}

M. Belén Hinojosa: Conceptualization, Investigation, Formal analysis, Visualization, Writing - original draft, Writing - review \& editing, Funding acquisition. Enrique Albert-Belda: Investigation, Formal analysis, Visualization, Writing - original draft, Writing - review \& editing. Beatriz Gómez-Muñoz: Investigation, Writing - original draft, Writing - review \& editing. José M. Moreno: Conceptualization, Supervision, Writing original draft, Writing - review \& editing.

\section{Declaration of competing interest}

The authors declare that they have no known competing financial interests or personal relationships that could have appeared to influence the work reported in this paper.

\section{Acknowledgements}

We are grateful to the anonymous reviewers for providing insightful comments and suggestions that helped to significantly improve the manuscript. Funding was provided by the Spanish Ministry of Economy, Industry and Competitiveness (FOCCLIM, CGL2016-78357-R) and Regional Ministry of Education in Castilla-La Mancha (RECUINCENDIO, POII-2014-017-A). E.A.B. is supported by a pre-doctoral grant cofunded by the Regional Castilla-La Mancha Government and the European Social Fund (SBPLY/16/180501/000145). The authors would like to thank INFOCAM technical staff, in particular to J. J. Fernández and J. P. García, for facilitating the geographical information of the study fire events and the access to the study plots.

\section{Appendix A. Supplementary data}

Supplementary data to this article can be found online at https://doi. org/10.1016/j.scitotenv.2020.141877.

\section{References}

Aerts, R., Chapin, F.S.I.I.I., 2000. The mineral nutrition of wild plants revisited: a reevaluation of processes and patterns. Adv. Ecol. Res. 30, 1-67. https://doi.org/ 10.1016/S0065-2504(08)60016-1.

Aguiar, M.R., Sala, O.E., 1999. Patch structure, dynamics and implications for the functioning of arid ecosystems. Trends Ecol. Evol. 14, 273-277. https://doi.org/10.1016/ S0169-5347(99)01612-2.

Anderson, P.E., 1982. Soil respiration. In: Page, A.L., Miller, R.H., Keeney, D.R. (Eds.) Methods of Soil Analysis. Part 2. Chemical and Microbiological Properties, Monogr.. vol. 9. Madison, WI, ASA, SSSA, pp. 831-872

Aponte, C., García, L.V., Marañón, T., 2013. Tree species effects on nutrient cycling and soil biota: a feedback mechanism favouring species coexistence. For. Ecol. Manag. 309, 36-46. https://doi.org/10.1016/j.foreco.2013.05.035.

Baudena, M., Santana, V.M., Baeza, M.J., Bautista, S., Eppinga, M.B., Hemerik, L., Mayor, A.G., Rodriguez, F., Valdecantos, A., Vallejo, V.R., Vasques, A., Rietkerk, M., 2020. Increased aridity drives post-fire recovery of Mediterranean forests towards open shrublands. New Phytol. 225, 1500-1515. https://doi.org/10.1111/nph.16252.

Beck, H.E., Zimmermann, N.E., McVicar, T.R., Vergopolan, N., Berg, A., Wood, E.F., 2018 Present and future Köppen-Geiger climate classification maps at 1-km resolution. Sci. Data 5, 180214. https://doi.org/10.1038/sdata.2018.214.

Bellot, J., Àvila, A., Rodrigo, A., 1999. Throughfall and stemflow. In: Rodà, F., Retana, J. Gracia, C.A., Bellot, J. (Eds.), Ecology of Mediterranean Evergreen Oak Forests. Springer, Berlin, Heidelberg, pp. 209-222.

Blank, R.R., ClementsTye, C., Harmon, M., 2017. Sagebrush wildfire effects on surface soil nutrient availability: a temporal and spatial study. Soil Sci. Soc. Am. J. 81, 1203-1210. https://doi.org/10.2136/sssaj2017.02.0039.

Bodí, M.B., Martin, D.A., Balfour, V.N., Santín, C., Doerr, S.H., Pereira, P., Cerdà, A., MataixSolera, J., 2014. Wildland fire ash: production, composition and eco-hydrogeomorphic effects. Earth Sci. Rev. 130, 103-127. https://doi.org/10.1016/j. earscirev.2013.12.007.

Bond, W.J., 2019. Open Ecosystems: Ecology and Evolution Beyond the Forest Edge. Oxford University Press.

Burns, R.G., Dick, R.P., 2002. Enzymes and the Environment. Activity, Ecology, and Applications. Marcel Decker, Inc, New York

Butler, O.M., Lewis, T., Rezaei Rashti, M., Maunsell, S.C., Elser, J.J., Chen, C., 2019. The stoichiometric legacy of fire regime regulates the roles of micro-organisms and invertebrates in decomposition. Ecology 100, e02732. https://doi.org/10.1002/ecy.2732.

Caldwell, M.M., 1994. 12 - exploiting nutrients in fertile soil microsites. In: Caldwell, M.M., Pearcy, R.W. (Eds.), Exploitation of Environmental Heterogeneity by Plants, 
Physiological Ecology. Academic Press, Boston, pp. 325-347 https://doi.org/10.1016 B978-0-12-155070-7.50017-2.

Caon, L., Vallejo, V.R., Ritsema, C.J., Geissen, V., 2014. Effects of wildfire on soil nutrients in Mediterranean ecosystems. Earth Sci. Rev. 139, 47-58. https://doi.org/10.1016/j. earscirev.2014.09.001.

Carreira, J.A., Niell, F.X., Lajtha, K., 1994. Soil nitrogen availability and nitrification in Mediterranean shrublands of varying fire history and successional stage. Biogeochemistry 26, 189-209. https://doi.org/10.1007/BF00002906.

Castells, E., Peñuelas, J., Valentine, D.W., 2004. Are phenolic compounds released from the Mediterranean shrub Cistus albidus responsible for changes in $\mathrm{N}$ cycling in siliceous and calcareous soils? New Phytol. 162, 187-195. https://doi.org/10.1111/j.14698137.2004.01021.x.

Cleary, M.B., Pendall, E., Ewers, B.E., 2010. Aboveground and belowground carbon pools after fire in mountain big sagebrush steppe. Rangel. Ecol. Manag. 63, 187-196. https://doi.org/10.2111/REM-D-09-00117.1.

Curiel, J., Baldocchi, D.D., Gershenson, A., Goldstein, A., Misson, L., Wong, S., 2007 Microbial soil respiration and its dependency on carbon inputs, soil temperature and moisture. Glob. Chang. Biol. 13, 2018-2035. https://doi.org/10.1111/j.13652486.2007.01415.x.

Dahlgren, R.A., Singer, M.J., Huang, X., 1997. Oak tree and grazing impacts on soil properties and nutrients in a California oak woodland. Biogeochemistry 39, 45-64. https:// doi.org/10.1023/A:1005812621312.

Davidson, E.A., Belk, E., Boone, R.D., 1998. Soil water content and temperature as independent or confounded factors controlling soil respiration in a temperate mixed hardwood forest. Glob. Chang. Biol. 4, 217-227. https://doi.org/10.1046/j.13652486.1998.00128.x

de Rigo, D., Caudullo, G., 2016. Quercus ilex in Europe: distribution, habitat, usage and threats. In: San-Miguel-Ayanz, J., de Rigo, D., Caudullo, G., Houston Durrant, T., Mauri, A. (Eds.), European Atlas of Forest Tree Species. Publ. Off. EU, Luxembourg (pp. e014bcd+).

de Román, M., de Miguel, A.M., 2005. Post-fire, seasonal and annual dynamics of the ectomycorrhizal community in a Quercus ilex L forest over a 3-year period. Mycorrhiza 15, 471-482. https://doi.org/10.1007/s00572-005-0353-6.

DeBano, L.F., Conrad, C.E., 1978. The effect of fire on nutrients in a chaparral ecosystem. Ecology 59, 489-497. https://doi.org/10.2307/1936579.

D'Odorico, P., Okin, G.S., Bestelmeyer, B.T., 2012. A synthetic review of feedbacks and drivers of shrub encroachment in arid grasslands. Ecohydrology 5, 520-530. https://doi.org/10.1002/eco.259.

Driscoll, D.A., Lindenmayer, D.B., Bennett, A.F., Bode, M., Bradstock, R.A., Cary, G.J., Clarke, M.F., Dexter, N., Fensham, R., Friend, G., Gill, M., James, S., Kay, G., Keith, D.A MacGregor, C., Russell-Smith, J., Salt, D., Watson, J.E.M., Williams, R.J., York, A., 2010. Fire management for biodiversity conservation: key research questions and our capacity to answer them. Biol. Conserv. 143, 1928-1939. https://doi.org/10.1016/j. biocon.2010.05.026.

Ettema, C.H., Wardle, D.A., 2002. Spatial soil ecology. Trends Ecol. Evol. 17, 177-183. https://doi.org/10.1016/S0169-5347(02)02496-5.

Eugenio, M., Lloret, F., Alcañiz, J.M., 2006. Regional patterns of fire recurrence effects on calcareous soils of Mediterranean Pinus halepensis communities. For. Ecol. Manag. 221, 313-318. https://doi.org/10.1016/j.foreco.2005.10.011.

Ferran, A., Delitti, W., Vallejo, V.R., 2005. Effects of fire recurrence in Quercus coccifera L. shrublands of the Valencia Region (Spain): II. Plant and soil nutrients. Plant Ecol. 177, 71-83. https://doi.org/10.1007/s11258-005-2141-y.

Fornara, D.A., Tilman, D., 2008. Plant functional composition influences rates of soil carbon and nitrogen accumulation. J. Ecol. 96, 314-322. https://doi.org/10.1111/ j.1365-2745.2007.01345x

Francos, M., Ubeda, X., Pereira, P., 2020. Long-term forest management after wildfire (Catalonia, NE Iberian Peninsula). J. For. Res. 31, 269-278. https://doi.org/10.1007 s11676-018-0867-3.

Gallardo, A., Rodríguez-Saucedo, J.J., Covelo, F., Fernández-Alés, R., 2000. Soil nitrogen heterogeneity in a Dehesa ecosystem. Plant Soil 222, 71-82. https://doi.org/10.1023/A 1004725927358.

García-Palacios, P. Maestre, FT. Bardgett, R.D. Kroon, H de, 2012. Plant responses to soil heterogeneity and global environmental change. J. Ecol. 100, 1303-1314. https://doi. org/10.1111/j.1365-2745.2012.02014.x.

Gómez-Rey, M.X., Madeira, M., Gonzalez-Prieto, S.J., Coutinho, J., 2013. Soil C and N dynamics in a Mediterranean oak woodland with shrub encroachment. Plant Soil 371, 339-354. https://doi.org/10.1007/s11104-013-1695-z.

Guénon, R., Vennetier, M., Dupuy, N., Roussos, S., Pailler, A., Gros, R., 2013. Trends in recovery of mediterranean soil chemical properties and microbial activities after infrequent and frequent wildfires. Land Degrad. Dev. 24, 115-128. https://doi.org/ 10.1002/ldr.1109.

Güsewell, S., 2004. N:P ratios in terrestrial plants: variation and functional significance. New Phytol. 164, 243-266. https://doi.org/10.1111/j.1469-8137.2004.01192.x.

Güsewell, S., Gessner, M.O., 2009. N:P ratios influence litter decomposition and colonization by fungi and bacteria in microcosms. Funct. Ecol. 23, 211-219. https://doi.org/ 10.1111/j.1365-2435.2008.01478x.

Güsewell, S., Koerselman, W., Verhoeven, J.T.A., 2003. Biomass N:P ratios as indicators of nutrient limitation for plant populations in wetlands. Ecol. Appl. 13, 372-384. https:// doi.org/10.1890/1051-0761(2003)013[0372:BNRAIO]2.0.CO;2.

Harris, I., Jones, P.D., Osborn, T.J., Lister, D.H., 2014. Updated high-resolution grids of monthly climatic observations - the CRU TS3.10 Dataset. Int. J. Climatol. 34, 623-642. https://doi.org/10.1002/joc.3711.

Hinojosa, M.B., Parra, A., Laudicina, V.A., Moreno, J.M., 2016. Post-fire soil functionality and microbial community structure in a Mediterranean shrubland subjected to experimental drought. Sci. Total Environ. 573, 1178-1189. https://doi.org/10.1016/j. scitotenv.2016.03.117.
Hinojosa, M.B., Laudicina, V.A., Parra, A., Albert-Belda, E., Moreno, J.M., 2019. Drought and its legacy modulate the post-fire recovery of soil functionality and microbial community structure in a Mediterranean shrubland. Glob. Chang. Biol. 25, 1409-1427. https://doi.org/10.1111/gcb.14575.

Hurlbert, S.H., 1984. Pseudoreplication and the design of ecological field experiments. Ecol. Monogr. 54, 187-211. https://doi.org/10.2307/1942661.

Hutchings, M.J., John, E.A., Wijesinghe, D.K., 2003. Toward understanding the consequences of soil heterogeneity for plant populations and communities. Ecology 84, 2322-2334. https://doi.org/10.1890/02-0290.

John, M.K., 1970. Colorimetric determination of phosphorus in soil and plant materials with ascorbic acid. Soil Sci. 109, 214-220. https://doi.org/10.1097/00010694197004000-00002.

Keeley, J.E., Bond, W.J., Bradstock, R.A., Pausas, J.G., Rundel, P.W., 2011. Fire in Mediterranean Ecosystems: Ecology, Evolution and Management. Cambridge University Press.

Keeney, D.R., Nelson, D.W., 1982. Nitrogen-inorganic forms. In: Page, A.L. (Ed.), Methods of Soil Analysis, Agronomy Monograph 9, Part 2. ASA, SSSA, Madison, WI, pp. 643-698.

Krawchuk, M.A., Moritz, M.A., Parisien, M.-A., Dorn, J.V., Hayhoe, K., 2009. Global pyrogeography: the current and future distribution of wildfire. PLoS One 4, e5102. https://doi.org/10.1371/journal.pone.0005102.

Li, J., Gilhooly, W.P., Okin, G.S., Blackwell, J., 2017. Abiotic processes are insufficient for fertile island development: a 10-year artificial shrub experiment in a desert grassland. Geophys. Res. Lett. 44, 2245-2253. https://doi.org/10.1002/2016GL072068.

López-Poma, R., Bautista, S., 2014. Plant regeneration functional groups modulate the response to fire of soil enzyme activities in a Mediterranean shrubland. Soil Biol. Biochem. 79, 5-13. https://doi.org/10.1016/j.soilbio.2014.08.016.

Maisto, G., de Marco, A., Meola, A., Sessa, L., Virzo De Santo, A., 2011. Nutrient dynamics in litter mixtures of four Mediterranean maquis species decomposing in situ. Soil Biol. Biochem. 43, 520-530. https://doi.org/10.1016/j.soilbio.2010.11.017.

Manzoni, S., Trofymow, J.A., Jackson, R.B., Porporato, A., 2010. Stoichiometric controls on carbon, nitrogen, and phosphorus dynamics in decomposing litter. Ecol. Monogr. 80, 89-106. https://doi.org/10.1890/09-0179.1.

Mariscal-Sancho, I., Santano, J., Mendiola, M.-Á., Peregrina, F., Espejo, R., 2010. Carbon dioxide emission rates and $\beta$-glucosidase activity in Mediterranean Ultisols under different soil management. Soil Sci. 175, 453-460. https://doi.org/10.1097/ SS.0b013e3181f51704.

Mayor, Á.G., Goirán, S.B., Vallejo, V.R., Bautista, S., 2016a. Variation in soil enzyme activity as a function of vegetation amount, type, and spatial structure in fire-prone Mediterranean shrublands. Sci. Total Environ. 573, 1209-1216. https://doi.org/10.1016/j. scitotenv.2016.03.139.

Mayor, A.G., Valdecantos, A, Vallejo, V.R, Keizer J., Bloem, J, Baeza, J. González-Pelayo, O., Machado, A.I., de Ruiter, P.C., 2016b. Fire-induced pine woodland to shrubland transitions in Southern Europe may promote shifts in soil fertility. Sci. Total Environ. 573, 1232-1241. https://doi.org/10.1016/j.scitotenv.2016.03.243.

McClain, M.E., Boyer, E.W., Dent, C.L., Gergel, S.E., Grimm, N.B., Groffman, P.M., Hart, S.C., Harvey, J.W., Johnston, C.A., Mayorga, E., McDowell, W.H., Pinay, G., 2003. Biogeochemical hot spots and hot moments at the interface of terrestrial and aquatic ecosystems. Ecosystems, 301-312 https://doi.org/10.1007/s10021-003-0161-9.

McCulley, R.L., Archer, S.R., Boutton, T.W., Hons, F.M., Zuberer, D.A., 2004. Soil respiration and nutrient cycling in wooded communities developing in grassland. Ecology 85, 2804-2817. https://doi.org/10.1890/03-0645.

McLean, E.O., 1982. Soil pH and lime requirement. In: Page, A.L., Miller, R.H., Keeney, D.R. (Eds.), Methods of Soil Analysis. Part 2. Chemical and Microbiological Properties, Monogr.. vol. 9. Madison, WI, ASA, SSSA, pp. 831-872

Müller, S.C., Overbeck, G.E., Pfadenhauer, J., Pillar, V.D., 2007. Plant functional types of woody species related to fire disturbance in forest-grassland ecotones. Plant Ecol. 189, 1-14. https://doi.org/10.1007/s11258-006-9162-z.

Neary, D.G., Klopatek, C.C., DeBano, L.F., Ffolliott, P.F., 1999. Fire effects on belowground sustainability: a review and synthesis. For. Ecol. Manag. 122, 51-57. https://doi.org/ 10.1016/S0378-1127(99)00032-8.

Nelson, D.W., Sommers, L.E., 1996. Total carbon, organic carbon, and organic matter. In: Sparks, D.L. (Ed.), Methods of Soil Analysis, Part 3, Chemical Methods. SSSA Book Series No 5. Madison, WI, ASA, SSSA, pp. 961-1010.

Nuñez-Olivera, E., Martinez-Abaigar, J., Escudero, J.C., 1996. Adaptability of leaves of Cistus ladanifer to widely varying environmental conditions. Funct. Ecol. 10, 636-646. https://doi.org/10.2307/2390174.

Odion, D.C., Davis, F.W., 2000. Fire, soil heating, and the formation of vegetation patterns in chaparral. Ecol. Monogr. 70, 149-169. https://doi.org/10.1890/0012-9615(2000) 070[0149:FSHATF]2.0.CO;2.

Oksanen, L., 2001. Logic of experiments in ecology: is pseudoreplication a pseudoissue? Oikos 94, 27-38. https://doi.org/10.1034/j.1600-0706.2001.11311.x.

Olsen, S.R., Sommers, L.E., 1982. Phosphorus. In: Page, A.L., Miller, R.H., Keeney, D.R. (Eds.), Methods of Soil Analysis. Part 2. Chemical and Microbiological Properties Monogr.. vol. 9. Madison, WI, ASA and SSSA, pp. 403-427

Pellegrini, A.F., Ahlström, A., Hobbie, S.E., Reich, P.B., Nieradzik, L.P., Staver, A.C., Scharenbroch, B.C., Jumpponen, A., Anderegg, W.R.L., Randerson, J.T., Jackson, R.B., 2018. Fire frequency drives decadal changes in soil carbon and nitrogen and ecosystem productivity. Nature 553, 194-198.

Rau, B.M., Blank, R.R., Chambers, J.C., Johnson, D.W., 2007. Prescribed fire in a Great Basin sagebrush ecosystem: dynamics of soil extractable nitrogen and phosphorus. J. Arid Environ. 71, 362-375. https://doi.org/10.1016/j.jaridenv.2007.05.006.

Rhoades, J.D., 1982. Cation exchange capacity. In: Page, A.L., Miller, R.H., Keeney, D.R. (Eds.), Methods of Soil Analysis. Part 2. Chemical and Microbiological Properties Monogr.. vol. 9. Madison, WI, ASA and SSSA, pp. 149-157 
Rodríguez-Echeverría, S., Pérez-Fernández, M.A., 2003. Soil fertility and herb facilitation mediated by Retama sphaerocarpa. J. Veg. Sci. 14, 807-814. https://doi.org/10.1111/ j.1654-1103.2003.tb02213.x.

Rundel, P.W., Arroyo, M.T.K., Cowling, R.M., Keeley, J.E., Lamont, B.B., Pausas, J.G., Vargas, P., 2018. Fire and plant diversification in Mediterranean-climate regions. Front. Plant Sci. 9, 851. https://doi.org/10.3389/fpls.2018.00851.

Sabaté, S., Sala, A., Gracia, C.A., 1995. Nutrient content in Quercus ilex canopies: seasonal and spatial variation within a catchment. Plant Soil 168, 297-304. https://doi.org/ 10.1007/BF00029341.

Sankey, J.B., Germino, M.J., Sankey, T.T., Hoover, A.N., 2012. Fire effects on the spatial patterning of soil properties in sagebrush steppe, USA: a meta-analysis. Int. J. Wildland Fire 21, 545-556. https://doi.org/10.1071/WF11092.

Santana, V.M., Baeza, M.J., Vallejo, V.R., 2011. Fuel structural traits modulating soil temperatures in different species patches of Mediterranean Basin shrublands. Int. J. Wildland Fire 20, 668-677. https://doi.org/10.1071/WF10083.

Santana, V.M., Baeza, M.J., Marrs, R.H., 2013. Response of woody and herbaceous fuel to repeated fires in Mediterranean gorse shrublands. Int. J. Wildland Fire 22, 508-514. https://doi.org/10.1071/WF12036.

Sardans, J., Peñuelas, J., 2013. Plant-soil interactions in Mediterranean forest and shrublands: impacts of climatic change. Plant Soil 365, 1-33. https://doi.org/ 10.1007/s11104-013-1591-6.

Saura-Mas, S., Lloret, F., 2009. Linking post-fire regenerative strategy and leaf nutrient content in Mediterranean woody plants. Perspect. Plant Ecol. Evol. Syst. 11, 219-229. https://doi.org/10.1016/j.ppees.2009.04.002.

Schade, J.D., Hobbie, S.E., 2005. Spatial and temporal variation in islands of fertility in the Sonoran Desert. Biogeochemistry 73, 541-553. https://doi.org/10.1007/s10533-0041718-1.

Schlesinger, W.H., Reynolds, J.F., Cunningham, G.L., Huenneke, L.F., Jarrell, W.M., Virginia, R.A., Whitford, W.G., 1990. Biological feedbacks in global desertification. Science 247, 1043-1048. https://doi.org/10.1126/science.247.4946.1043.

Sinsabaugh, R.S., 1994. Enzymatic analysis of microbial pattern and process. Biol. Fertil. Soils 17, 69-74. https://doi.org/10.1007/BF00418675.

Soil Survey Staff, 2006. Keys to Soil Taxonomy. 10th ed. USDA-Natural Resources Conservation Service, Washington, DC.

StatSoft, Inc, 2007. STATISTICA (data analysis software system), version 8.0. www.statsoft. com.
Tabatabai, M.A., 1994. Soil enzymes. In: Weaver, R.W., Angle, J.S., Botttomley, P.S. (Eds.) Methods of Soil Analysis: Microbiological and Biochemical Properties. ASA, SSSA Madison, WI, pp. 775-833.

Titus, J.H., Nowak, R.S., Smith, S.D., 2002. Soil resource heterogeneity in the Mojave Desert J. Arid Environ. 52, 269-292. https://doi.org/10.1006/jare.2002.1010.

Toberman, H., Chen, C., Lewis, T., Elser, J.J., 2014. High-frequency fire alters C:N:P stoichiometry in forest litter. Glob. Chang. Biol. 20, 2321-2331. https://doi.org/10.1111/ gcb.12432.

Urbieta, I.R., Franquesa, M., Viedma, O., Moreno, J.M., 2019. Fire activity and burned forest lands decreased during the last three decades in Spain. Ann. For. Sci. 76, 90. https:// doi.org/10.1007/s13595-019-0874-3.

Van de Vijver, C.A.D.M., Poot, P., Prins, H.H.T., 1999. Causes of increased nutrient concentrations in post-fire regrowth in an East African savanna. Plant Soil 214, 173-185. https://doi.org/10.1023/A:1004753406424.

van Mantgem, P., Schwartz, M., Keifer, M., 2001. Monitoring fire effects for managed burns and wildfires: conning to terms with pseudoreplication. Nat. Areas J. 21 266-273.

Verdú, M., 2000. Ecological and evolutionary differences between Mediterranean seeders and resprouters. J. Veg. Sci. 11, 265-268. https://doi.org/10.2307/3236806.

Villar-Salvador, P., Valladares, F., Domínguez-Lerena, S., Ruiz-Díez, B., Fernández-Pascual, M., Delgado, A., Peñuelas, J.L., 2008. Functional traits related to seedling performance in the Mediterranean leguminous shrub Retama sphaerocarpa: insights from a provenance, fertilization, and rhizobial inoculation study. Environ. Exp. Bot. 64 145-154. https://doi.org/10.1016/j.envexpbot.2008.04.005.

Vitousek, P.M., Howarth, R.W., 1991. Nitrogen limitation on land and in the sea: how can it occur? Biogeochemistry 13, 87-115.

Wang, G., Li, J., Ravi, S., Dukes, D., Gonzales, H.B., Sankey, J.B., 2019. Post-fire redistribution of soil carbon and nitrogen at a grassland-shrubland ecotone. Ecosystems 22 174-188. https://doi.org/10.1007/s10021-018-0260-2.

Weise, D.R., Biging, G.S., 1996. Effects of wind velocity and slope on flame properties. Can. J. For. Res. 26, 1849-1858. https://doi.org/10.1139/x26-210.

Whelan, R.J., 1995. The Ecology of Fire. Cambridge Studies in Ecology. Cambridge University Press, Cambridge.

Wright, I.J., Westoby, M., 2003. Nutrient concentration, resorption and lifespan: leaf traits of Australian sclerophyll species. Funct. Ecol. 17, 10-19. https://doi.org/10.1046 j.1365-2435.2003.00694.x. 